\title{
AUTHORS’ AND ARTISTS' MORAL RIGHTS: A COMPARATIVE LEGAL AND ECONOMIC ANALYSIS
}

\author{
HENRY HANSMANN and MARINA SANTILLI*
}

\begin{abstract}
In recent years the United States has followed other common-law jurisdictions, as well as most of the civil-law jurisdictions of western Europe, in adopting legislation recognizing artists' "moral rights." While there has been extensive debate about that legislation, to date there has been little effort at sustained analysis, from an economic point of view, of the functions that moral rights might perform. This article offers such an analysis, arguing that moral rights doctrine serves, among other purposes, to control reputational externalities to the potential benefit, not just of the individual artist, but of other owners of the artist's work and of the public at large. The article also discusses the importance of copyright doctrine in performing a similar role and explores the merits of supplementing or replacing moral rights doctrine with a broader and more flexible system of display rights for visual artists.
\end{abstract}

\section{INTRODUCTION}

$I$ $\mathrm{N}$ many nations, including most of western Europe, the law has long recognized interests of authors and artists in their work that are separate from copyright and that can be retained by an author or artist even after he has transferred his copyright to another person or persons and (in the case of visual arts, such as painting or sculpture) has also parted with the physical work of art itself. Principal among these legally recognized interests are four distinct rights that are commonly referred to collectively as authors' and artists" "moral rights": the right of integrity, under which the artist can prevent alterations in his work; the right of attribution or paternity, under

* Hansmann is Professor, Yale Law School. Santilli is Professor, Faculty of Law, University of Pisa. This essay derives from a presentation prepared for a meeting of the Comparative Law and Economics Forum in Brussels, August 1993, and has subsequently been presented at workshops at the University of Chicago, Columbia, New York University, and Yale, and at the Fifth Symposium on Law and Economics at Travemünde, Germany. For helpful comments and discussions we are grateful to the participants in those sessions and also, particularly, to Ian Ayres, Rochelle Dreyfuss, Jane Ginsburg, Michael Klausner, William Landes, Dean Leuck, Robert Merges, Roberta Romano, and Diane Zimmerman.

[Journal of Legal Studies, vol. XXVI (January 1997)]

(C) 1997 by The University of Chicago. All rights reserved. 0047-2530/97/2601-0003\$01.50 
which the artist can insist that his work be distributed or displayed only if his name is connected with it; the right of disclosure, under which the artist can refuse to expose his work to the public before he feels it is satisfactory; and the right of retraction or withdrawal, under which the artist can withdraw his work even after it has left his hands. Most countries that recognize these rights make them, to a greater or lesser degree, inalienable.

In contrast, the common-law countries, including conspicuously the United States, historically not only have failed to make explicit provision for such continuing rights of artists in their work but have legal regimes that effectively render unenforceable any effort by an individual artist to craft and retain such rights in his own creations after he has transferred the other elements of ownership. Thus, patterns of rights that are mandatory under the civil-law regimes of Europe have been forbidden by the common law. This is in strong contrast to the usual relationship between these two legal systems: in general, the common law is far more hospitable to the creation of divided property rights than is the civil law.'

These differing views of authors' and artists' rights are often presented as a basic distinction between the intellectual property law regimes found in the civil-law countries and those found in the common-law countries. ${ }^{2}$ They have long been a subject of considerable debate and controversy, and increasingly so in recent years as the United States and the European Community have struggled to determine whose policies concerning intellectual property will dominate the international legal order. ${ }^{3}$ One important focus of this controversy has been the Berne Convention on Copyright, originally drafted in 1886 , which requires that signatory countries provide protection for moral rights, including particularly the rights of paternity and integrity. For more than 100 years the United States refused to sign the Berne Con-

\footnotetext{
1 As a matter of general doctrine, the civil law seeks to assure that all rights in a given item of property are held by a single owner, limiting deviations from this arrangement to a restricted set of narrowly defined categories. One consequence of this approach is that the private trust, which has long been a familiar institution in common-law countries, cannot as a general matter be formed under the civil law, since it recognizes simultaneous property interests in both the trustee and the beneficiary. See Henry Hansmann \& Ugo Mattei, The Functions of Trust Law: A Comparative Legal and Economic Analysis (working paper, Yale Law School 1996).

${ }^{2}$ See generally Neil Netanel, Alienability Restrictions and the Enhancement of Author Autonomy in United States and Continental Copyright Law, 12 Cardozo Arts \& Ent. 1, 2 (1994); Paul E. Geller, Toward an Overriding Norm in Copyright: Sign Wealth, 159 Revue internationale du droit d'auteur [hereinafter R.I.D.A.] 3, 27 (1994).

${ }^{3}$ See, for example, Silke Von Lewinski, The Role of Copyright in Modern International Trade Law, 161 R.I.D.A. 1, 4 (1994); Herman Cohen-Jehoram, The EC Copyright Directives: Economics and Authors' Rights, 25 Int'l Rev. Indus. Prop. \& Copyright L. [hereinafter I.I.C.] 821 (1994).
} 
vention, in part because of objections to the moral rights clause. ${ }^{4} \mathrm{Then}$, in 1989, the United States reversed its position and signed, ${ }^{5}$ claiming that U.S. law had evolved to the point where it could be construed, as a whole, to provide the minimal protection for artists' moral rights required by the Convention-and noting further that, even if U.S. law did not provide this minimum protection, other signatory countries were also not in compliance, yet nobody had ever objected. ${ }^{6}$

Many commentators have long argued that, to bring the United States more closely into compliance with the Berne Convention, to establish greater harmony between U.S. law and that of the European Community, and to improve the status of authors and artists, the law in the United States should be reformed to provide greater protection for authors' and artists' moral rights. ${ }^{7}$ Partly in response to these pressures, various laws extending these rights have been enacted over the past 2 decades. At least 11 states now explicitly recognize moral rights in greater or lesser degree, ${ }^{8}$ and in 1989 Congress enacted the federal Visual Artists Rights Act (VARA), which makes provision for the rights of integrity and attribution. ${ }^{9}$ Moreover, even in the absence of specific legislation, American courts have at times offered protection for interests analogous to moral rights through extension of common-law rights or through expansive interpretation of particular statutory rights, such as the trademark laws. Still, it is often argued that more should be done. ${ }^{10}$

Interest in this subject is also high outside the United States. The scope of artists' moral rights varies considerably from one European country to another-with France being generally the most expansive-thus leading to debates as to which regime is superior and to difficulties in harmonizing law among the member states of the European Union. ${ }^{11}$ Moreover, within

\footnotetext{
4 See Adolf Dietz, The Artist's Right of Integrity under Copyright Law-a Comparative Approach, 25 I.I.C. 177, 179 (1994).

5 The signing of the treaty followed congressional passage of the Beme Convention Implementation Act of 1988, Pub. L. 100-568, 102 Stat. 2853 (1988).

6 Ralph S. Brown, Adherence to the Berne Copyright Convention: The Moral Right Issue, 35 J. Copyright Soc'y 196, 205 (1987-88).

7 See Gerald Dworkin, Moral Rights and the Common Law Countries, 5 Australian Intell. Prop. J. 5 (1994).

${ }^{8}$ See, generally, Thomas Goetzl, California Art Legislation Goes Federal: Progress in the Protection of Artists' Rights, 15 Hastings Comm. \& Ent. L. J. 893 (1993).

9 Visual Artists Rights Act of 1990 (VARA), codified at 17 U.S.C. $\$ \S 101,102,106(a)$, 107,601 .

${ }^{10}$ See, for example, Jane Ginsburg, Moral Rights in a Common Law System, in Moral Rights Protection in a Copyright System 18 (Peter Anderson \& David Saunders eds. 1992).

1 See A. Dietz, Copyright Law in the European Community (1978); 1995 European Commission Green Paper on copyright and Related Rights in the Information Society, ch. 2, Sec. 7 (Moral Rights), in Journal, Copyright Society of the U.S.A. 50, 103-6 (1996).
} 
individual European countries there is often considerable controversy about the precise interpretation to be given existing statutory and decisional law concerning artists' moral rights.

Although there already exists an extensive legal literature on moral rights, ${ }^{12}$ that literature largely lacks systematic analysis from an economic point of view. ${ }^{13}$ In this essay we seek to fill that gap. Our principal objective is not to advance specific normative proposals but rather to clarify debate on the subject, exploring the functions served by moral rights and illuminating the pros and cons of various doctrinal alternatives. ${ }^{14}$ We also seek, more broadly, to offer insight into the general functions served by copyright doctrine and into the character and role of the general rules of law, found in all jurisdictions, that severely limit the possibilities for creating divided property rights.

It has sometimes been said that economic analysis offers little insight into the appropriate assignment of entitlements of the sort involved in artists' moral rights. ${ }^{15}$ But we believe that, on the contrary, economic analysis is extremely helpful here, as elsewhere, in developing a clearer and more systematic understanding of the interests served by legal rules and institutions and in analyzing the effectiveness of particular rules and institutions in serving those interests.

Many countries that provide for artists' moral rights, and also the state of California, have in addition adopted what the French term the droit de suite, under which painters, sculptors, and other visual artists have a right to receive a fraction of the price paid on each subsequent resale of a work of art they have created. In a companion essay we discuss the issuesclosely related to those discussed here-that are raised by the droit de suite and by resale and display royalties for works of art in general. ${ }^{16}$

${ }^{12}$ For references, see Paul Goldstein, Copyright's Highway, From Guttenberg to the Celestial Jukebox 170 (1994); Moral Rights Protection in a Copyright System (Peter Anderson \& David Saunders eds. 1992).

${ }^{13}$ See, however, G. Hadfield, The Economics of Copyright: An Historical Perspective, 38 Copyright L. Symp. I (ASCAP 1992); P. Goldstein, supra note 12, at 173-79; Roberta Romano, The Author's Right to Credit: An Economic Analysis for Providing Copyright Protection (working paper, Yale Law School 1980).

${ }^{14}$ Our article is therefore much in the spirit of the work of Landes and Posner, exploring the closely related fields of trademark and copyright. William Landes \& Richard Posner, Trademark Law: An Economic Perspective, 30 J. Law \& Econ. 265 (1987); William Landes \& Richard Posner, An Economic Analysis of Copyright Law, 18 J. Legal Stud. 79 (1989); William Landes, Copyright Protection of Letters, Diaries, and Other Unpublished Works: An Economic Approach, 21 J. Legal Stud. 79 (1992).

is See, for example, Gunnar G. Karnell, The Berne Convention between Author's Rights and Copyright Economics—an International Dilemma, 26 I.I.C. 193, 193-99 (1995); Alain Strowel, Droit d'auteur et copyright: Divergences et convergences 135 (1993).

${ }^{16}$ Henry Hansmann \& Marina Santilli, Resale Royalties for Works of Art: A Comparative Legal and Economic Analysis (working paper, Yale Law School 1996). 
We shall here proceed by discussing, in turn, each of the four basic moral rights. We begin with the right of integrity, which is both the most important of the moral rights from a practical standpoint and the one that best illustrates the issues raised by moral rights in general. For economy of expression, we shall generally use the term "artists" throughout to refer collectively to both visual artists (such as painters and sculptors) and to authors of literary works. ${ }^{17}$

\section{The Right OF INTEgRITY}

The right of integrity is described in the Berne Convention as follows: "Independently of the author's economic rights, and even after the transfer of said rights, the author shall have the right . . . to object to any distortion, mutilation, or other modification of, or other derogatory action in relation to, the said work, which would be prejudicial to his honor or reputation." 18 This language is paralleled by the language found in the statutes of most countries that recognize the right of integrity, although individual jurisdictions often deviate from the Berne Convention's phrasing in various ways that expand, contract, or clarify its reach. ${ }^{19}$

A prototypical, and famous, application of the right of integrity involved a refrigerator that was painted by the French artist Bernard Buffet and contributed by him to a charity auction. The individual who purchased the refrigerator proceeded to cut it into six panels that he intended to sell sepa-

17 European legal language does the reverse, using the expression "authors' rights"' to encompass the rights of both authors and visual artists.

${ }_{18}$ Paris Act of the Berne Convention, Article 6bis. Unless otherwise noted, all references are to the Paris Act of the Berne Convention, S. Treaty Doc. No. 27, 99th Cong., 2d Sess. 37 (1986) [hereinafter Berne Convention].

19 The range of actions to which the artist can object is described variously as "any distortion, mutilation, or any other modification ... capable of prejudicing [the artist's] honor or reputation" (Italy, Law No. 63 of April 22, 1941, arts, 20-24), translated and reprinted as amended in 2 Copyright Laws \& Treaties of the World (BNA), Item 1, at 3-4 (Supp. 198183) [hereinafter Italian Copyright Act]; "any distortion or any other mutilation of his work which would prejudice [the artist's] lawful intellectual or personal interests in the work", (Germany, Uhreberrechtgesetz [Law on copyright and neighboring rights of September 9, 1965], ch. 4, arts. 12-14, BGB1.I S. 1273 [hereinafter German Copyright Act], trans. as amended in 1993 in 30 Copyright, Monthly Rev. World Intell. Prop. Org., Laws \& Treaties Insert [hereinafter Copyright (WIPO)]); "any intentional distortion, mutilation or other modification ... which would be prejudicial to [the artist's] honor or reputation" and "any intentional or grossly negligent destruction" of "a work of recognized stature" (Visual Artist's Rights Act of 1990 [VARA], 17 U.S.C. $\S \S 106$ A, 113(d)). The French statute, generally considered to be the broadest, is also the most general; it simply says that an artist "shall enjoy the right to respect for his name, his authorship, and his work. This right shall be attached to his person." (France, Law No. 95-597 of July 1, 1992, J.O. July 3, 1992, at 8801, Art. L. 121-1, codified in Code de la Propriété Intellectuelle [hereinafter C. Prop. Intellectuelle], trans. as amended by Law No. 92-1336 of December 16, 1992, in Copyright (WIPO), France Text 3-01 (October 1994)). Unless otherwise noted, all references hereafter are to the JulyAugust 1993 WIPO translation. 
rately, evidently to increase its resale value. Buffet sued the purchaser of the refrigerator to prevent the selling of his dismembered work, invoking his right of integrity under French law, and won his case. ${ }^{20}$

Similar protection was not generally available under American law prior to the recent state and federal enactments. A prominent example involves a massive mobile by Alexander Calder that was purchased at an exhibition by a private collector and then donated to the Pittsburgh airport. The airport repainted the black and white sculpture in green and gold-the colors of Allegheny County - and also, over Calder's protests, altered the orientation of the sculpture's elements and soldered them to prevent movement. For the remaining 18 years of his life, Calder sought to have the work restored to its original state but was unsuccessful. ${ }^{21}$

In the civil-law countries, the right of integrity applies not just to painting, sculpture, and the other visual arts but also to literary works. This is in contrast to the United States, where recent federal and state legislation recognizing moral rights has generally been confined to the visual arts. In the discussion that follows, we focus largely on the application of the right of integrity to the visual arts, and particularly to painting, sculpture, and other forms of artistic expression in which the work of art is primarily embodied in a single unique object rather than (as in the case of movies) in multiple reproductions. We have chosen this focus because unique works of art illustrate most clearly the functions served by the right of integrity and because for literary works, as we explain further below, copyright doctrine serves (at least in the United States) many of the same functions that might otherwise be served by the right of integrity. Most of our analysis, however, applies to literary works as well as to the visual arts.

\section{A. Creating Divided Property Rights}

Jurisdictions that recognize the right of integrity give artists continuing property rights in their work. Thus, even after a painter has sold one of his paintings, and that painting has subsequently been resold again several times over, the artist can still take legal action directly against the current

20 Judgment of July 6, 1962 (l'affaire Bernarad Buffet), Cour d'appel, Paris, Recueil Dalloz [D. Jur.] 570. See John H. Merryman, The Refrigerator of Bernard Buffet, 27 Hastings L. J. 1023 (1976). But see Strowel, supra note 15 , at 500 , for a slightly different interpretation. For applications of the right of integrity in the United States under state and federal law, see Peter H. Karlen, Moral Rights and Real Life Artists, 15 Hastings Comm. \& Ent. L. J. 929 (1993). See also Richard Mayer, California Arts Legislation Goes Federal, 15 Hastings Comm. \& Ent. L. J. 981 (1993).

${ }^{21}$ Two years after Calder's death, however, the airport agreed to restore the mobile as Calder had desired. Diana Rose, Calder's Pittsburgh: A Violated and Immobile Mobile, Art News, January 1978, at 39. 
owner if that owner seeks to alter the painting in ways inconsistent with the artist's right of integrity. Absent the doctrine of moral rights, it would not be possible, in general, for an artist to retain such a continuing interest in his work after its sale. ${ }^{22}$ Under both European and American contract law, a seller of a chattel generally cannot reserve rights in the chattel, of either an affirmative or a negative character, that are enforceable against subsequent purchasers even if those purchasers have notice of the initial seller's intention to reserve such rights. (Of course, by means of contract, a seller can retain rights against the initial purchaser, with whom he is in privity of contract.) Moral rights legislation changes this rule in the case of works of art, permitting the artist, in effect, to maintain a continuing negative servitude in his work, analogous to the servitudes that can be created in real property in both civil-law and common-law systems.

The law's general prohibition on servitudes in chattels is not difficult to rationalize on efficiency grounds. It seems unlikely that such servitudes would often be valuable: sellers of objects do not generally have important interests, separate from and stronger than those of other persons, that could be affected by the use of the object in the hands of subsequent owners. At the same time, servitudes can seriously impede the use and transferability of property, since they impose on owners the burden of keeping track of any servitudes and, when a use inconsistent with a servitude seems worthwhile, of locating and negotiating with the owner of the servitude to seek permission.

The law's willingness to enforce easements, covenants, and equitable servitudes on real property, where the benefit of the servitude "touches and concerns" neighboring property, presumably reflects (1) the potentially large advantages in coordinating the uses of parcels of property that are, by their nature, bound in a spatial relationship to each other regardless of their separate ownership, (2) the relatively low costs to the owner of the burdened parcel of remaining informed of the burden, and (3) the ease of obtaining release when that is desirable. Similarly, the few special cases in which the law permits the enforcement of servitudes on chattels-such as security interests in personal property $y^{23}$ or resale price maintenance ${ }^{24}$-arguably involve circumstances in which (1) unrestricted use of the burdened chattel by subsequent purchasers threatens substantial harm to the person enjoying the benefit of the servitude, (2) subsequent purchasers can easily

${ }^{22}$ See Zechariah Chafee, Jr., Equitable Servitudes on Chattels, 41 Harv. L. Rev. 945 (1928); Zechariah Chafee, Jr., The Music Goes Round and Round: Equitable Servitudes and Chattels, 69 Harv. L. Rev. 1250 (1956).

${ }^{23}$ U.C.C. $\$ 9-306(2)$.

${ }^{24}$ See Note, The Operation of Fair-Trade Programs, 69 Harv. L. Rev. 316 (1955). 
be put on notice of the servitude, and (3) it is not too difficult for subsequent purchasers to obtain release from the servitude where appropriate.

If the right of integrity can be rationalized as a reasonable exception to the general prohibition on servitudes in chattels, presumably it is because similar conditions are met. In particular, it must be true that the actions of current owners of works of art can seriously affect the interests of the artists who created those works or of other persons. Those interests are therefore worth examining with care.

\section{B. The Interests Protected by the Right of Integrity}

It is frequently said that the interests protected by moral rights doctrine, and particularly by the right of integrity, are "personality" interests that are fundamentally different from the "economic" or "commercial" interests that are protected by the copyright, trademark, and right of publicity doctrines that, until recently, were the principal bodies of law governing the interests of artists in the United States. ${ }^{25}$ This characterization is reinforced by the language of the legislation in which moral rights are embodied, typified by the Berne Convention provision quoted above, which speaks of moral rights as being independent of "the author's economic rights." Although this characterization contains some truth, it also has its limitations. In particular, the interests protected by the right of integrity can have a distinctly commercial character, in the sense that the right can play an important role in protecting the market value of private property. Moreover, the right of integrity can serve to protect not just the pecuniary and nonpecuniary interests of the artist, but the interests-both pecuniary and nonpecuniary-of other persons as well.

\section{Nonpecuniary Interests of the Artist}

Physical alteration of an artist's work after the work has left the artist's hands, or prejudicial display of the work, can harm the artist in a variety of ways. The most direct is simply the subjective personal anguish the artist feels from seeing his work abused, quite apart from-and even in spite of-what anyone else might think about it. Thus, an artist may identify with his works as with his children: prize them for their present character and not want that character changed. Or he may be trying to communicate something to others, whether they want to receive the message or not. ${ }^{26}$

${ }^{25}$ See Geller, supra note 2, at 5, 25-27; Roberta Kwall, The Right of Publicity vs. the First Amendment: A Property and Liability Rule Analysis, 70 Ind. L. J. 47, 59-60 (1994).

${ }^{26}$ See Marci Hamilton, Art Speech, 49 Vand. L. Rev. 73 (1996). 
(The interests of those who might receive the communication are discussed later below.) Or he may wish to have a personal reputation as the kind of person who creates certain types of works, even if those works are not the most marketable.

For all these reasons, an artist may wish to maintain the integrity of his works after he has sold them, even if that reduces the value of the works to their current owners and to other prospective purchasers. ${ }^{27}$ The right of integrity permits an artist to do this. Moreover, at least where the right is waivable (an issue we discuss below), it encourages the artist to do so in a socially efficient ${ }^{28}$ manner. An artist who, for his own subjective reasons, casts his work in a form that is unpopular with potential purchasers, and retains his right of integrity to protect that form, will receive a lower initial sale price for the works as a consequence and thus will internalize the costs as well as the benefits of his choice.

All artisans, of course, presumably feel some attachment to their work and suffer when it is mutilated or mocked. Nevertheless, the law does not generally let them impose a servitude on their work preventing alteration or abuse. Why should the law treat artists more favorably? Perhaps because creators of those works we label "art," which are typically unique and highly individual works that require substantial skill and effort, commonly feel a peculiarly strong attachment of this sort. Moreover, the types of work we label art are generally acquired principally for their expressive or decorative character, and not for functional or utilitarian uses, and hence are less likely than other chattels to need modification to serve their functions

\footnotetext{
${ }^{27}$ For example, it was claimed by some-including, conspicuously, the prominent art critic and collector Clement Greenberg-that the metal sculptures of the American artist David Smith would be improved, aesthetically and perhaps in market value, if they were free of the paint that the artist insisted on applying to them. For this reason, it has been said, Greenberg had a number of Smith's painted sculptures stripped-though Smith had strongly expressed his opposition to such treatment of his work. There was no remedy at the time for Smith, since VARA was not then in force. (Moreover, Greenberg's actions took place after the artist's death, when rights under VARA would have expired.) And, since Greenberg was a trustee of Smith's estate, there may have been nobody both able and willing to bring suit posthumously in any event. See Rosalind Krauss, Changing the Work of David Smith, 62 Art in Am. 30 (September-October 1974), reprinted in 1 John H. Merryman \& Albert E. Elsen, Law, Ethics, and the Visual Arts 4-36 (2d ed. 1987); R. Mayer, supra note 20.

28 We use the term "efficient" here in the economist's very broad sense of that wordthat is, to refer to a situation in which there is no alternative arrangement that could make any person better off, by his own subjective valuation, without making other persons worse off to a greater degree. This is not a calculus limited to commercial or financial values; it comprises all subjective values, including esthetic, cultural, and emotional ones. Thus "efficiency" as used here is much broader than the concept of "economic value" or "commercial value" as the latter is often talked about in the intellectual property literature, where the latter concepts are commonly contrasted with "cultural value" or "personality" interests.
} 
well-modifications that might conflict with the artist's subjective interest in the work's integrity. ${ }^{29}$

Commentary on moral rights often, explicitly or implicitly, focuses on the potential for this type of subjective nonpecuniary harm as the principal justification for the right of integrity. ${ }^{30}$ And perhaps it is an adequate justification. We suspect, however, that much of the incentive for adopting moral rights legislation derives from other considerations, and particularly from the fact that those works we label "art'" commonly involve important reputational externalities, thus giving both the artist and others an unusually strong interest in protecting the integrity of individual works.

\section{Pecuniary Interests of the Artist}

The language of the Berne Convention, and the similar language found in many nations' statutes, describes the right of integrity in terms of protection from actions that are "prejudicial to [the artist's] honor or reputation." This suggests that the right of integrity serves, in important part, to protect not just artists' personal feelings about their creations but rather (or in addition) their reputational interests. Those interests can, moreover, have a strongly pecuniary character.

In particular, alteration of works that an artist has already sold can, by damaging his reputation, lower the prices he can charge for other work that he sells subsequently. Buffet's refrigerator provides an example. The purchaser of the refrigerator evidently felt he could increase his total proceeds from resale of the work by subdividing it, so that he could sell the artist's name, as it were, six times. If much of the artist's work were cut up this way, however, his reputation as a whole could suffer. While the entire refrigerator of Buffet presumably had value as an artistic work in its own right, owning a mere panel of the refrigerator would probably have had value in large part just because the artist was known to have created other work of strong artistic value-which means, among other things, work that has a conceptual integrity, rather than just bits and pieces. Put differently, the seller of the refrigerator panels was, in an important sense, selling Buffet's other work. The same is true with the Calder mobile in the Pittsburgh airport. Given the fame of Calder's work as a whole, and given in particular the distinctive color schemes that have become familiar in Calder's work in general, the repainted mobile in the airport gains special notoriety. But, if all of Calder's work were altered and painted in such a fashion, that

\footnotetext{
29 See, however, the discussion of site-specific art in note 39 infra.

${ }^{30}$ See André Kerever, Copyright: The Achievements and Future Development of European Legal Culture, 26 Copyright (WIPO) 130 (1990).
} 
work-and hence Calder's name-would be less famous, and the prices Calder could charge for subsequent work would fall.

In effect, each of an artist's works is an advertisement for all of the others. The situation is analogous to a franchise. An individual franchisee has an incentive to skimp on quality, cutting his individual costs while still enjoying the reputation for high quality that is associated with the franchise in general. But, in doing so, he is free riding on the other franchisees and imposing a cost on them. For this reason, franchisors commonly impose strong quality standards on their individual franchisees. For the same reason, an artist has an interest in preventing the reputation of his work in general from being depreciated by the opportunistic adulteration of individual works. A franchisor, however, can protect his interests through his ongoing contractual relationship with his franchisee, whereas an artist does not have such a continuing contractual relationship with the purchasers of his work. Consequently, if the artist is to be given the same type of control, he must be given some device, such as the right of integrity, that goes beyond the tools generally available under the law of contracts.

Does it make sense for protection of this reputational interest to outlive the artist? Perhaps so, since his estate may well contain unsold works, and since the right of integrity may also serve to support the value of works by the artist, and of copyrights in his work, that are held by the artist's heirs.

\section{Interests of Other Owners of the Artist's Work}

Another way of describing the reputational interests just discussed is that, with a work of art such as a painting or a sculpture, there is other property-namely, the artist's other artistic creations-that constitutes a "dominant tenement" that benefits from the servitude imposed on the artist's work by the right of integrity. Damage to one of the artist's works, in effect, imposes external costs on the artist's other works.

Often a substantial portion of this other work will be in the hands, not of the artist himself, but of art collectors, galleries, and museums. By protecting the artist's reputation, the right of integrity therefore protects the interests of these other persons as well. Indeed, in the case of an artist whose productive career is finished and who has sold all of his works, it may be only these other persons whose pecuniary interests are protected by the right of integrity. Their interests, moreover, may last well past the artist's death and the expiration of the artist's copyrights.

\section{Interests of the Public at Large}

Not only the artist himself, and the other individuals who currently own works (or copyrights in the works) created by that artist, but also the public at large may have an interest in protecting the integrity of an artist's work. 
One source of this public interest is that great works of art often become important elements in a community's culture: other works of art are created in response to them, and they become common reference points or icons that are widely shared in social communication. The loss or alteration of such works would therefore be costly to the community at large, depriving that community, as it were, of a widely used part of its previously shared vocabulary. ${ }^{31}$ Yet, since these community benefits have the character of a public good, the current owner of the artwork has insufficient incentive to protect them by protecting the work itself.

This community interest in works of art is explicitly recognized in European statutes that protect and preserve those works that are considered important to the nation's artistic heritage. ${ }^{32}$ The United States does not have general legislation of this sort, although it does have specific legislation for particular types of art, ${ }^{33}$ including legislation governing colorization of movies $^{34}$ and architectural landmark preservation laws. ${ }^{35}$ The artist's right of integrity might be seen as a further means by which these interests of the public at large are protected, supplementing the other more specific statutory protections just mentioned.

A related public interest in the integrity of a work of art concerns the work as the embodiment of an idea. A painting, for example, may represent an important aesthetic innovation, or it may be a uniquely persuasive statement of a social critique or ideal. ${ }^{36}$ Yet, though the idea embodied in the work is valuable to society, that value may not be well reflected in the value of the work to its private owner, who cannot easily charge others for what they learn from the painting, and who may face a low market value for the work owing to the generally conservative tastes of the most prosperous collectors and museums. Consequently, the owner may not only have insufficient incentive to protect and display the work, but may even have an incentive to alter or destroy it.

${ }^{31}$ Compare Geller, supra note 2, at 6, 39-43, 75-83; J. Merryman, The Moral Right of Maurice Utrillo, 43 Am. J. Comp. L. 445-54 (1995).

${ }^{32}$ On the relevant Italian law, see S. Ferreri, The Status of Cultural Property in Private International Law, from an Italian Point of View, in Italian National Reports to the Fourteenth International Congress of Comparative Law. On French law, see J. Chatelain \& F. Chatelain, Oeuvre d'art et objects de collection en droit francais 18-132 (1990).

${ }^{33}$ See Karen Gantz, Protecting Artists' Moral Rights: A Critique of the California Art Preservation Act as a Model for Statutory Reform, 49 Geo. Wash. L. Rev. 873, 876 n. 16 (1981); Merryman, supra note 31.

${ }^{34}$ National Film Preservation Act of 1992, 2 U.S.C. $\S 179$.

${ }^{35}$ For recent discussions, see P. Gerstenblith, Architect as Artist: Artist's Rights and Historic Preservation, 12 Cardozo Arts \& Ent. L. J. 431, 455-65 (1994); N. Wargo, Copyright Protection for Architecture and the Berne Convention, 65 N.Y.U. L. Rev. 434-39 (1990).

${ }^{36}$ See Umberto Eco, La definizione dell'arte 265 (1990). 
Finally, the public at large-that is, people who do not (yet) own copies of an artist's work-have an interest in not being misled about that work. For example, the purchaser of a work by Picasso is actually purchasing the work as Picasso created it, and not some adulterated version of one of that artist's works. (In particular, he will want to avoid suffering the loss that could be expected if and when it is discovered that the work has been adulterated.) The right of integrity might to some extent serve to protect the public in this regard. But this is perhaps best seen as an incidental and not a primary function of the right of integrity, because the doctrine does not give the public any protection when the artist himself participates in the deception $^{37}$ and because other more general antifraud doctrines can serve this function as well. In any case, the right of attribution raises these consumer protection issues more clearly, and we shall discuss them further below in that context.

\section{Mixed Interests}

Although, for clarity of analysis, it is helpful to focus separately on the interests of the artist, of other owners of the artists' work, and of the public at large, those interests are of course interconnected. Not only an artist's financial returns from his work, but also his subjective sense of satisfaction with his work quite apart from those returns, will often correlate strongly with the value placed on his work by purchasers of art and with the extent to which his work is considered important by the public at large. Consequently, when the right of integrity serves one of these interests, it will frequently serve the others as well.

There can, however, be situations in which these interests are in conflict. The least troublesome are those in which the artist insists on keeping his work in a form that reduces its value to prospective purchasers. As we remarked above, permitting the artist to deploy the right of integrity to protect his own interests here is in principle unproblematic, since the artist will internalize both the costs and benefits of his choices. More difficult situations pit the interests of the public at large against those of the artist. For example, to prevent what they felt was a false or unfavorable presentation of their work, painters have sometimes sought to invoke the right of integrity to prevent their work from being displayed to the public in the absence of other works by that painter or together with works of particular other paint-

\footnotetext{
${ }^{37}$ For example, both De Chirico and Dali were said to have signed-presumably for compensation-paintings actually created by other artists. See Ragghianti, Il caso De Chirico, (1970); Lewis Hyde, Imagination and the Erotic Life of Property, ch. 8 (1983); L. Catterall, The Great Dali Art Fraud and Other Deceptions (1992).
} 
ers. ${ }^{38}$ These situations require the courts to balance the conflicting interests involved, comparing the benefits to the current owner of the disputed use with the costs that the use imposes on the artist and others. In this balancing, a rough efficiency calculus, seeking the solution with the largest net benefits, seems appropriate and is arguably more or less what the courts employ. ${ }^{39}$

\section{What Is Art?}

We have suggested here that an important function of the right of integrity is to protect the value of the artist's oeuvre as a whole-in effect, the artist's reputation-from opportunistic actions by the owners of individual works. With this in mind, we can discern two criteria for determining the type of work to which it is most appropriate to extend the right of integrity - that is, to determine for this purpose "What is art?" 40 First, knowl-

38 See Judgment of March 25, 1955 (Ente autonomo "La Biennale" di Venezia c. De Chirico), Foro It. 1955. I. 717 (artist De Chirico filed suit, complaining that retrospective exhibition of his works overincluded his earlier paintings and underincluded his later works, thus violating his moral rights).

39 One implicit application of this kind of calculus in U.S. law can be found in the doctrine of "fair use," which limits both copyright and moral rights in ways that serve to balance the interests of the artist and of the public where those interests come into conflict in ways that cannot easily be resolved by voluntary transactions-for example, where parodies are involved. See Geri Yonover, Artistic Parody: The Precarious Balance: Moral Rights, Parody, and Fair Use, 14 Cardozo Arts \& Ent. L. J. 79 (1996).

Site-specific art, particularly when publicly displayed, creates particular opportunities for conflict between the artist's right of integrity and the interests of the public at large. See Serra v. General Services Administration, 847 F.2d 1045 (2d Cir. 1988), rejecting the sculptor Richard Serra's protests over the removal, owing to popular protests, of his sculpture Tilted Arc from the site for which it was specifically commissioned and designed, Federal Plaza in New York City. (The sculpture and the site were the property of the U.S. General Services Administration, which made the decision to remove it. Serra, whose suit preceded the enactment of VARA, based his claim on First Amendment and due process grounds.) It is perhaps not surprising, then, that the first major judicial interpretation of VARA, Carter v. Helmsley-Spear, Inc., 71 F.3d 77 (1995), involves site-specific art-namely, sculptures commissioned and designed specifically for the lobby of a building. The Court of Appeals in that case decided that the sculpture was "work for hire" and thus excluded from protection under VARA. (We discuss the work for hire doctrine below in connection with the right of attribution.) This conclusion, which is arguable, had the advantage of avoiding potentially unpleasant consequences: deciding for the plaintiffs-the sculptors-might have imposed substantial costs on the owners of the building, though the work had not been commissioned by the owners but rather by a former tenant that subsequently became insolvent.

${ }^{40}$ For other approaches, see VARA, 17 U.S.C. $\$ 101$ (1990); Dietz, supra note 11, at 18386; P. H. Karlen, What Is Art? A Sketch for a Legal Definition, 94 L. Q. Rev. 383, 387-88 (1978); Tom Wolfe, The Painted Word (1975); Roger A. McCain, Markets for Work of Art and the "Market for Lemons," in Economic Policy for the Arts 130, 135 (William S. Hendon et al. eds. 1980); Geller, supra note 2, at 51-59. 
edge of the artist's name is considered informative or useful in assessing the work. Put in commercial terms, this means that the work of art sells for more if it can be attributed to the artist than if it is anonymous. Second, the reputation of the artist is, in turn, based on the entire body of work he has created.

Where the second element is missing, damage to one of an artist's works would not affect the value of the artist's other works. For example, where a person is famous for reasons unconnected to his art, it is possible that one of his paintings would sell for a large amount of money simply because of a reputation he acquired elsewhere-say, as a movie star or politician. In such a case, damage to one of the person's paintings might have no detrimental effect on his reputation in general and on the value of his other paintings in particular.

Clearly, at least in the twentieth century, much work that we term "art" meets the two criteria just suggested. This is reflected in the widespread concern for ascertaining the authenticity of works of art, in the sense of assuring that they are in fact the work of the individual to whom they are ascribed. There is much theorizing about why the identity of the artist has become so important in modern culture. ${ }^{41}$ For the present, we need not be concerned about the sources of the phenomenon but rather need only note its great contemporary importance in the field of art. ${ }^{42}$ Given this strong connection between the value of a work of art and the identity of the artist who created it, both the artist and the other owners of the artist's work have a special interest in protecting the "integrity" of the artist's work as a whole. ${ }^{43}$

European law in general, and French law in particular, often speaks of moral rights doctrine as being aimed at protecting the "personality" of the artist. ${ }^{44}$ One might take this as an indication that the principal purpose of the law is to protect the artist from the nonpecuniary subjective harm he might suffer from seeing his work abused. But, for the reasons just described, one could also take it as support for the view that moral rights are intended to protect the artist's reputation. For, from the public's point of

${ }^{41}$ See Strowel, supra note 15, at 79, 83, 85; William D. Grampp, Pricing the Priceless: Art, Artists, and Economics 127 (1989); S. Hochfield, When the Master's a Mistress, Art News, October 1994, at 28; Wolfe, supra note 40, at 113-20.

${ }^{42}$ See Leslie P. Singer, Phenomenology and Economics of Art Markets: An Art Historical Perspective, 12 J. Cultural Econ. 27, 30-31, 33, 34 (1988).

${ }^{43}$ VARA arguably recognizes this when, in defining what a "work of visual art" is for purposes of the right of integrity, it requires that the work be signed by the artist (and in fact requires very little else). 17 U.S.C. $\$ 101$.

${ }^{44}$ See Strowel, supra note 15, at 481-537. 
view, an artist's body of work is an important component of his "personality.' 'That is, for an artist, reputation and personality become one and the same.

In support of the view that reputational externalities are an important justification for the right of integrity, it is noteworthy that, in contrast to artists, inventors are generally not granted the right of integrity-even though inventors are highly creative and are otherwise given property rights in their inventions of a character similar to those given artists, and even though inventors are sometimes, like artists, granted the right of attribution. ${ }^{45} \mathrm{~A}$ plausible justification for this distinction between inventors and artists is that the marketability of an invention has little relationship to the personal identity of the inventor and, in particular, to the other items that the inventor has patented. That is, one of an individual's inventions generally does not gain higher value because he is known to have invented something else as well. It is important for Marconi that he invented the radio, hence the right of attribution; it is not important for the radio that Marconi invented it, hence no right of integrity. ${ }^{46}$

\section{Destruction of Art Works}

A particularly interesting problem in defining the scope of the right of integrity, and one that illustrates nicely some of the conflicting interests affected by that right, involves the destruction of works of art. Although alteration or mutilation of works of visual art may be infringements of the right of integrity in the civil-law countries, complete destruction of a work of art generally is not. ${ }^{47}$ VARA's right of integrity also does not extend to complete destruction, except for works of "recognized stature.", 48

Putting their financial interests aside, in general artists, whether they are successful or not, presumably would prefer not to have their work destroyed, even after they have sold the work. The public at large-that is, persons who do not personally own one of the artist's works-presumably

${ }^{45}$ For example, in Italy inventors are granted a right of attribution under the patent law. Sec. 7, 14 R.D., June 29, 1939, n.1127.

46 Another plausible justification for not extending the right of integrity to inventors is that patent law already provides inventors with substantial control over the licensing of their invention, so that an explicit right of integrity would not appreciably extend their controljust as copyright law, discussed below, provides the authors of literary works with the potential for exercising much of the same type of control that the right of integrity could offer those authors.

${ }^{47}$ See Dietz, supra note 4, at 190-91.

48 VARA provides that an artist "shall have the right to prevent any destruction of a work of recognized stature, and any intentional or grossly negligent destruction of that work is a violation of that right." 17 U.S.C. $§ 106(a)(3)(B)$. 
are also best served in general by preservation of all of the work of an established artist and are unaffected one way or the other by destruction of the work of artists who will never have a substantial reputation.

From a pecuniary point of view, however, an artist's interests are more ambiguous, as are those of other owners of the artist's works. On the one hand, as we have noted, each of an artist's works serves as an advertisement for the others, and its merits also tend to be reflected positively, by association, in the value of the artist's other works. In this respect, then, destruction of one of an artist's works reduces the value of the others-including works not yet sold or even produced by the artist. On the other hand, destruction of one of an artist's works increases the scarcity value of the others, ${ }^{49}$ and in this respect tends to increase their market value. We cannot say with certainty, therefore, whether destruction of one of an artist's works will have, on net, a negative or positive effect on the financial welfare of the artist and of other owners of his work.

In addition to these sometimes conflicting interests, there are also the costs of preserving a work of art. Where, as is true in the vast majority of cases, the artist in question will never establish a reputation of any significance, and her work will never have a meaningful resale market, the costs of preserving her work could well exceed any modest reputational benefits that preservation would yield. It is presumably for this reason that VARA limits its right against destruction to works of "recognized stature." But, so limited, the right against destruction may be largely empty, since rarely would the owner of a work of "recognized stature" have an incentive to destroy it. VARA may therefore, in practice, be little different from the right of integrity as commonly construed in the civil-law countries, where it provides no protection at all against complete destruction of a work of art.

If effect, the civil-law countries leave the owner of a work of art with a simple dichotomous choice. They can preserve the work unaltered, either keeping it for their personal enjoyment or selling it to someone who values it more, or they can destroy it. They have an incentive to follow the latter course only if the costs of preserving the work exceed the benefit of the

\footnotetext{
49 "Scarcity value" here has two different components. First, there is the usual quantity price trade-off from conventional price theory: as supply is reduced for substitutable goods, the market price for those goods increases. Second, there is the possibility that works of art are a form of "collectable" good whose value to its owner derives in significant part simply from its scarcity - which is to say that the utility that a given painting yields to its possessor (and not just the price for which she can sell it) is inversely proportional to the number of other paintings similar to it that are in existence. If the paintings of a given painter exhibit the latter characteristic, then it is possible that, even if it were costless to preserve all of them, destruction of one of them would be socially efficient.
} 
work to any potential purchaser. Since the potential purchasers include the artist himself, ${ }^{50}$ this helps assure-though it does not guarantee-that works will be destroyed if and only if that is the efficient course.

\section{E. Doctrinal Alternatives to the Right of Integrity}

We shall say more below about the substantive scope of the right of integrity. The choices involved will be easier to analyze, however, after the following discussion of other doctrines that serve as potential alternatives to the right of integrity.

\section{Copyright}

By permitting authors and artists to reserve a continuing property right in expressive works they create, the law of copyright, like moral rights doctrine, establishes an exception to the general prohibition on servitudes in property other than real estate. ${ }^{51}$

The conventional justification for the law of copyright is that it transforms what would otherwise be a public good-the ability to copy an author's work-into a private good, and in so doing creates stronger incentives for authors to create new works. But the law of copyright goes substantially further than this. By imposing appropriate restrictions on her transfers of copyright, the author of a literary work can not only establish a property right in all copies made of her work but also exercise substantial control over the quality of those copies. That is to say, modern copyright law permits an author to subdivide her copyright, retaining some aspects of it and transferring others. ${ }^{52}$ Only the particular rights transferred can be exercised by the transferee or, more important for the subject at hand, retransferred by the transferee to a third party. In particular, an author can decline to transfer the right to alter the work or to adapt it (for example, for a movie), insisting that it be reproduced only in its original form, and this restriction on the rights transferred will bind any subsequent third party

\footnotetext{
50 The potential for reselling a work to the artist who created it, under threat of destroying it, might invite some strategic threats in an effort to extort substantial surplus from the artist. Perhaps for this reason, the 1992 revisions to the Swiss law of author's rights requires an owner of a work of art, before destroying it, to offer to sell the work to its artist for the value of the materials it contains. Swiss Federal Act on Copyright and Neighboring Rights of October 9, 1992 (RS 231.1), sec. 15.

51 See Thomas M. S. Hemnes, Restraints on Alienation, Equitable Servitudes, and the Feudal Nature of Computer Software Licensing, 71 Den. U. L. Rev. 577 (1994).

5217 U.S.C. $\$ 201(\mathrm{~d})(2)$
} 
transferees of the copyright as well. ${ }^{53}$ Indeed, unless there is contrary language in the contract, when an author assigns the copyright in her work, the law assumes that she reserves the right to approve of any modifications in that work that are not clearly necessary and appropriate for the purpose for which the assignment was undertaken. ${ }^{54}$ Copyright therefore permits the author of a literary work to protect herself in very substantial degree against any harm she might suffer from alteration of her work.

Copyright law also permits an author to protect herself in some degree from injury that might result from prejudicial presentation of her workthat is, to control the context in which her work is published. For example, an author of short stories who does not wish her work to be published in anthologies where it might be associated or compared with works by certain other authors could transfer the copyright to publish the story in collections of the author's own stories, but not in anthologies.

The law of copyright could have been constructed narrowly to give an author a monopoly in her original creation without giving her control over the ways in which that monopoly is exploited once it has been transferred to other persons. That is, the law could have required that, if she transfers her copyright, she must transfer it in its entirety. One reason why modern copyright law permits an author to subdivide her copyright, retaining portions of it and transferring the rest, is evidently that this facilitates the assignment of different types of reproduction rights to different specialized publishers-say, hardcover book rights to a publisher and film rights to a movie production company. Another important reason, however, is presumably that this ability of an author to limit the authority she grants to transferees of her copyright permits her to protect herself against the harms she can suffer from misuse of her work. Whether such protection was an intended purpose or simply a by-product of the divisibility of copyright, the law of copyright as presently structured permits authors of literary works to avoid the same types of harm to which the right of integrity is addressed.

${ }^{53}$ See National Bank of Commerce v. Shaklee Corp., 503 F. Supp. 533 (W.D. Tex. 1980) (finding copyright infringement when defendant inserted unauthorized advertising material into published work); Frank Music Corp. v. Metro-Goldwyn-Mayer, Inc., 772 F.2d 505 (9th Cir. 1985) (finding copyright infringement by defendant who staged musical revue in manner not allowed under license); Cohen v. Paramount Pictures Corp., 845 F.2d 851 (9th Cir. 1988) (finding copyright infringement when defendant with right to record musical composition for film and display film on television also sold and rented videocassettes).

54 See Gilliam v. American Broadcasting Co. (ABC), 583 F.2d 14 (2d Cir. 1976) (holding that, in addition to violating the Lanham Act, ABC's modification of comedy sketches by Monty Python infringed the comedy group's copyright in the work, and that the fact that $\mathrm{ABC}$ had purchased rights to sketches from the British Broadcasting Corporation (BBC), which had not repeated in its contract with $A B C$ restrictions on alterations contained in BBC's licensing agreement from Monty Python, created no defense to Monty Python's action against $\mathrm{ABC}$, since a "grantor may not convey rights greater than it owns"). 
A separate right of integrity therefore offers only modest additional protection to authors of literary works. That additional protection comes, where it exists at all, principally in one of three forms. First, it permits broader control than does copyright over the contexts in which work is presented to the public. For example, in Italy the right of integrity has been interpreted to permit a composer and singer who was known for his environmentalism to prevent an assignee of the copyright in his songs from selling cassettes containing those songs in conjunction with environmentally harmful detergent. ${ }^{55}$ In the United States, in contrast, copyright law has been interpreted not to permit a songwriter to exert control over the products to which purchasers of his recordings could tie those recordings when marketing them. ${ }^{56}$

Second, even where a statutory right of integrity does not permit an author to retain rights that he could not otherwise retain through conditions on his grants of copyright, it effectively inserts a default term in all assignments of copyright imposing such conditions unless the author specifically waives or transfers them-hence reducing contracting costs and avoiding inadvertent transfers of rights that most authors might wish to retain. Third, where the right of integrity is inalienable, that right in effect imposes a term in the assignment of copyright that is not merely a default term but a mandatory term.

Although painters, sculptors, and other visual artists can retain copyright in their works even after they have sold the original, that copyright covers principally reproductions; it gives the artist much less control over the uses made of his original painting or sculpture once that object is sold by the artist. As a consequence, copyright is more useful to authors of literary works than it is to visual artists as a means of controlling the way in which their work is presented to the public. For example, while an author of a short story can license publication rights to the story in collections of the author's own works while declining to permit anthologizing of the work with stories by other authors, a painter cannot sell his painting subject to the condition that it be displayed publicly only in shows confined to the artist's own works. As we discuss below, copyright for works of visual art might have been constructed more flexibly, to incorporate display rights. As it is, however, so far as the law of copyright is concerned, when an artist sells his original work of art he sells all rights concerning its display to the current owner of the work and cannot impose servitudes on that right.

The situation is somewhat more ambiguous when it comes to alterations of the original work of art itself. Serious alterations could be construed to

55 Pretore of Rome, November 15, 1986, Diritto di Autore 155 (1987).

56 Burke \& Van Heusen v. Arrow Drug, 233 F. Supp. 881 (E.D. Pa. 1964). 
involve the creation of an "adaptation" or a "derivative work of art" as those terms are used in copyright law. Since the right to create adaptations or derivative works is among the interests protected by copyright, a visual artist who reserves all of his copyright in his work can prevent alterations of the work that constitute an adaptation or derivative work, and this right is enforceable against all subsequent purchasers of the artist's original work of art. The division of Buffet's refrigerator into six separate panels, for example, would arguably constitute the creation of derivative work, as would the reconfiguration and repainting of Calder's mobile by the Pittsburgh airport. A separate right of integrity, therefore, might be unnecessary to protect artists against the kinds of abuse involved in these situations.

One reason why Calder was unsuccessful in obtaining a remedy against the Pittsburgh airport, presumably, was that he had not retained his copyright in the mobile and thus had given up his right to prevent creation of adaptations or derivative works based on it. Prior to the 1976 revision of the U.S. copyright act, it was presumed, under the "Pushman doctrine," that a visual artist transferred common-law copyright to her work when she transferred the physical object itself, unless she specifically reserved her copyright in the contract of sale. ${ }^{57}$ Since few artists, apparently, specifically reserved their copyright, this meant that they could not protect the integrity of their works through exercise of the right to prevent creation of adaptations or derivative works. Perhaps for this reason, the U.S. case law defining the scope of this form of protection for visual artists, as opposed to authors of literary works, is poorly developed. ${ }^{58}$ This is presumably an important reason why the U.S. VARA legislation of 1990 establishing a right of integrity extends that right only to visual artists and not to authors of literary works, and even for the visual arts does not generally extend to reproductions.

Following the reversal of the Pushman doctrine in 1976, continuing judicial refinement of what constitutes an adaptation or derivative work in the context of the visual arts might eventually have given rise to doctrine clearly giving visual artists a substantial degree of control over prejudicial alteration of their work - control quite similar to that which is provided by the right of integrity in the civil-law countries. Or it might not have: courts might have been strongly inclined to defer to the property rights of owners of art works when they came into conflict with the artist's personal and reputational interests. As it is, with the enactment of VARA's right of integrity in 1990, pressure for further doctrinal evolution along these lines has

\footnotetext{
${ }^{57}$ Pushman v. New York Graphic Soc'y, 287 N.Y. 302 (1942).

${ }^{58}$ See Donald M. Millinger, Copyright and the Fine Artist, 48 Geo. Wash. L. Rev. 354, 358 (1979-80).
} 
largely disappeared.$^{59}$ For the purposes at hand, however, the doctrinal label-right of adaptation or right of integrity-does not much matter. What we are primarily concerned with here is the justification and appropriate scope for servitudes that artists are permitted to retain in their work, under whatever name.

\section{Trademark Law}

Some of the interests protected by a right of integrity also receive protection in the United States under state and federal trademark law, and particularly under a catchall provision of the Lanham Act (the federal trademark statute) that outlaws false representations of goods or services. ${ }^{60}$ For example, the British comedy group Monty Python was able to invoke the latter provision to enjoin a U.S. television network from broadcasting a bowdlerized version of some of their television sketches, on the grounds that the broadcast could injure their reputation. ${ }^{61}$ Since reputational interests are arguably the most important of the interests protected by the right of integrity, there is substantial logic in this approach.

Further expansive interpretation of trademark law might be sufficient to give artists the same type of reputational protection afforded by the right of integrity. ${ }^{62}$ At present, however, the reach of trademark law seems more modest than that. It might not provide protection to an artist who does not already have a substantial reputation; ${ }^{63}$ it might provide no protection where an artist's name is removed from an altered work before its display; it might not apply to altered works that are not displayed commercially or resold; and it might not prevent complete destruction of a work. Yet protection in these latter circumstances could be quite important to artists.

In any event, the adoption of VARA, with its explicit grant of a right of integrity, has probably forestalled further development of trademark doctrine in this direction.

59 VARA requires reputational injury, however, while the adaptation right arguably does not, so that the latter potentially still gives broader protection than the former.

${ }^{60}$ Lanham Act \$ 43(a), 15 U.S.C. \$ 1125(a).

${ }^{61}$ Gilliam, supra note 54.

${ }^{62}$ Building, in particular, on Lanham Act $\S 43(a)$ and on state trademark law protection against dilution of reputation by passing off debased productions as originals.

${ }^{63}$ Thus the name "Picasso" has been granted protection as a trademark under the Lanham Act, but only because the great familiarity of the name, and the form of the signature itself, had given it "secondary meaning." Visual Arts and Galleries Ass'n v. Various John Does, 80 Civ. 4487 (1980); see Tim Jensen, The Selling of Picasso: A Look at the Artist's Rights in Protecting the Reputation of His Name, 6 Art \& L. 77 (1981). 


\section{Display Rights}

Under U.S. copyright law, the copyright granted to the author of a dramatic work, or to the composer of a musical composition, extends to individual performances of the work. Consequently, the author can insist on royalties for each performance. It has sometimes been argued that an analogous "display right"' should be included in the copyright granted to painters, sculptors, and other visual artists, permitting those artists to reserve to themselves the right to display a work of art publicly even after selling possession of the physical object itself. ${ }^{64}$ Under such a display rights regime, presumably a painter could, for example, sell one of his paintings subject to the condition that, if it is ever displayed by a museum, the artist must be paid royalties measured by some index of the total viewership that the painting receives.

In a companion article, we discuss the wisdom and practicality of developing such a system of display rights as a means of providing appropriate financial incentives for visual artists. ${ }^{65}$ For the purposes at hand, the important point is that, if such a system of display rights were established, it could give to visual artists much the same kind of continuing control over the presentation of their work that copyright currently provides for authors of literary works. That is, display rights could be used by an artist, not just as a means of extracting royalties, but also or instead as a means of controlling the conditions under which the artist's work is presented to the public.

At a minimum, display rights would presumably permit an artist to license owners of his works to display those works intact, but not with alterations - that is, to assure himself of essentially the same degree of protection that is afforded by the right of integrity. But display rights could also afford an artist much broader, more affirmative, and more discretionary control over the presentation of his work than does the right of integrity as typically interpreted. Thus, display rights might be construed to permit an artist sufficient control to withhold the right to display his works in particular contexts that, although not so prejudicial as to constitute an infringement of the right of integrity, are considered by the artist to be disadvantageous to his general reputation. ${ }^{66}$ And display rights could also permit an artist to

${ }^{64}$ Note, Copyright Royalties for Visual Artists: A Display-Based Alternative to the Droit de Suite, 76 Cornell L. Rev. 510 (1991); Thomas Goetzl \& Stuart Sutton, Copyright and the Visual Artist's Display Right: A New Doctrinal Analysis, 9 Colum.-VLA J. L. \& Arts 15 (1984).

${ }^{65}$ Hansmann \& Santilli, supra note 16.

${ }^{66}$ The right of integrity has sometimes been interpreted to permit visual artists to prevent display of their work under conditions they felt were unfavorable to it. For example, the heirs of an Italian artist succeeded in preventing a display of a portion of the artist's work in a fashion suggesting that it was his complete oeuvre: Tribunale of Verona, October 13, 1989, 
insist that owners of his works consent to reasonable requests to lend the works for major museum shows and other temporary exhibitions, thus allowing the artist to ensure that each of his individual works will continue to promote the artist's general reputation (and hence benefit the owners of his works as a group).

As it is, U.S. copyright law already grants to the owner of the copyright in "pictorial, graphic, or sculptural works" the exclusive right "to display the copyrighted work publicly." 67 Since visual artists may-indeed, are presumed to-retain their copyright when they transfer ownership of their work itself, ${ }^{6}$ this language in itself would seem adequate to create a display right of the type described above. This language is severely qualified, however, by another provision in the Copyright Act that specifically permits the owner of a copy (including the original) 69 of a copyrighted work "without the authority of the copyright owner, to display that copy publicly . . . to viewers present at the place where the copy is located.' 70 In short, when the creator of a work of visual art sells that work, he sells the right to display it. In the structure of the Copyright Act, the provision giving the copyright owner the right to display the work publicly serves simply to reinforce the copyright owner's ability to prevent unauthorized reproduction of the work-for instance, to display the original or a copy to viewers who are not located "at the place where the copy is located."

In essence, the difference between the right of integrity and a display right is the difference between a narrow tort-type right and a much broader property-type right. The right of integrity permits an artist to sue for injunction or damages when his work is mistreated in ways that cause conspicuous injury to his reputation. To effectuate the right, an artist must convince a court that the use made of his work causes him unreasonable injury. ${ }^{71}$ Display rights, in contrast, would permit an artist to retain a property right in his work - the right to display his work in general, or under specified conditions - whose content he could determine largely for himself, without hav-

\footnotetext{
61 Diritto di Autore 397-407 (1990). But the control over display that artists have been given under the right of integrity has generally been quite restricted. For example, some painters were unsuccessful in arguing that their right of integrity was violated when their work were displayed in the Venice Biannale of 1968 together with that of conceptualist artists of whom they disapproved. Tribunale of Venice, May 8, 1968, Diritto di Autore 58-63 (1970).

6717 U.S.C. $\$ 106(5)$.

6817 U.S.C. $\$ 202$.

6917 U.S.C. $\$ 101$ (defining "copies" as material objects in which a work is fixed, and specifically including in the definition of a copy "the material object . . . in which the work is first fixed'").

7017 U.S.C. \& 106(5).

71 See the cases cited in note 66 supra.
} 
ing to convince a court that the forms of display that he seeks to bar are unreasonably injurious.

If protection of the various interests discussed above-and particularly the artist's reputational interest-justifies creation of a tort-type right of integrity, does it also follow that those interests justify, more broadly, recognition of display rights for visual artists? Perhaps it does. But there are several reasons why it might not.

First, there is the problem of notice. A legally defined right of integrity effectively puts all owners of artwork on notice that they hold the work subject to certain commonly defined restraints on the uses they can make of it. With display rights, notice costs would be higher. An owner of a work of art would have to consult either the documentation that accompanied the original sale of the work by the artist, or some central registry where display rights are recorded, to determine the scope of the rights retained by the artist.

Second, since it is difficult to predict the uses to which art might be put in the future, an artist who wishes to obtain effective control might have to reserve display rights that are so broad or vague as to seriously reduce the market value of the work (since, among other things, potential purchasers might be concerned that an artist could become opportunistic or eccentric in the exploitation of his display rights). Perhaps the best that could be done in practice would be to deny to an owner-by reserving to the artist-the right to alter or display or otherwise use the work in ways that would be "unreasonably" damaging to the artist's interests, where "unreasonable" is intended to mean "inefficient" in the sense that the benefits to the owner from the intended (mis)use would be smaller than the costs imposed on the artist and other interested persons, and where it would ultimately fall to the courts to be the arbiters of what is unreasonable in any given case. But the result would then be very similar to the tortlike statutory right of integrity. And, since all artists would presumably wish to withhold authority for such unreasonable uses of their work, there is an argument for simply implying such a clause in all contracts for the sale of artistic works-which is effectively what is accomplished by the right of integrity.

Third, for many types of art, such as oil paintings and traditional sculptures, the potential for conflicts of interest between the artist and the current owner of the work may be quite small. Only rarely would the current owner be tempted to alter the work or otherwise use it in a way that would seriously affect the interests of the artist or of other persons who have an interest in the artist's work. Establishing a full legal regime of servitudes to deal with those rare cases may be overkill and provide as well the potential for creating a variety of inefficient divided property interests. A tortlike right of integrity has the advantage that it can be invoked to deal with the few 
problem cases that arise, while otherwise leaving the structure of property rights in simple form.

It could be, however, that if the law were to permit artists to reserve display rights, then, as with copyright, important participants in the art market-including galleries as well as trade groups representing artists and museums - might well devise industrywide standard forms for those rights, establish simple means for recording and notice, and even create specialized mechanisms for dispute resolution, while judicial doctrines of reasonableness and desuetude would evolve to help clear away display rights that are outdated or highly idiosyncratic, thus creating an efficient and flexible scheme of tradeable property rights that obviates the need for the tortlike right of integrity.

\section{Leasing}

An artist who wishes to retain the kind of control over her creations that a full system of display rights would afford can already establish that control simply by leasing rather than selling her works and inserting in the terms of the lease any restrictions she desires.

Apart from giving the artist control over the maintenance and presentation of her work, a true lease, in which the possessor pays for the consumption value of possession currently with periodic rental payments rather than ex ante with a lump-sum purchase price, offers both advantages and disadvantages as a means of transferring possession of works of art. Among the important advantages are that it gives an artist a strong incentive to continue producing art that will enhance her reputation and, hence, the value of the other work that she has produced - that is, it internalizes what would otherwise be a reputational externality. Among the disadvantages are that it requires an artist to defer receipt of income far into the future, and it prevents her from passing some of the riskiness of her career on to collectors who can diversify it by collecting the work of many artists. If, on net, the disadvantages outweigh the advantages - an issue we discuss at greater length elsewhere ${ }^{72}$ - an alternative would be a nominal lease with the bulk of the "rent" paid in anticipation, while annual rental payments are confined to the proverbial peppercorn. If such a lease were made very long-term and freely assignable, and gave the possessor an inexpensive purchase option at the end, it might have very much the character of a sale subject to retention of specified display rights.

Casual empiricism suggests that artists in fact often lend their work, rather than selling it or donating it, when the work is extremely sensitive

${ }^{72}$ Hansmann \& Santilli, supra note 16. 
to the way in which it is displayed or maintained, as in the case of works that must be specifically modified for each space in which they are displayed, or dynamic works with delicate or adjustable operating parts. This implies that the creators of such work place substantial importance on maintaining control over it and that a more flexible system of artists' rights, such as a right of integrity or a system of display rights, could offer them substantial benefits.

At the same time, leasing is evidently rare with more traditional forms of painting and sculpture, which instead are typically sold outright. This might be taken as evidence that a full-fledged system of display rights would have little value for the creators of such works - so that artists generally would not retain display rights even if the law made that a possibilityand it might even be taken to suggest that the relatively narrow tortlike right of integrity has at most marginal practical value for artists as well. The rarity of leasing is not entirely probative on these issues, however. First, even a nominal lease requires that periodic contact be maintained between an artist and the current possessor of his work, which is a burden that is avoided with both a right of integrity and display rights. Second, leasing requires that each time possession of an artwork is transferred (that is, the lease is assigned), the acquirer must go through the bother of acquainting himself with the particular terms of the lease. While a similar burden would be imposed on transfers by display rights, it is avoided by the right of integrity since that right imposes the same burdens in all cases. Third, use of a purely nominal lease carries the risk that the lease will be construed by the courts as creating, in reality, a sale subject to a servitude and, hence, will be declared unenforceable.

\section{F. Standing to Enforce the Right of Integrity}

Having surveyed the principal alternatives for protecting interests of the kind protected by the right of integrity, we return to considering that right itself and the structure that the law gives it. We begin with rights to enforce.

\section{While the Artist Is Alive}

In all jurisdictions, the artist, and only the artist, is given the right to enforce the artist's right of integrity during the artist's lifetime. This is not a perfect arrangement, however. The artist may have interests that diverge from those of the other owners of his work, or of the public at large. This is especially likely to be the case for an artist who has reached the end of his productive career, and who has already sold nearly all of the work that he has produced, so that he no longer has a significant financial interest in 
maintaining his reputation. ${ }^{73}$ If such an artist should, for example, find himself in financial need late in his life, he might be tempted to accept payment from the owner of one or more of his works to waive his right of integrity in circumstances where the benefits from the waiver are smaller than the collective harm imposed on other owners of the artist's work-permitting, say, a slightly disreputable company that has purchased one of his most famous mobiles to repaint the mobile in the company's trademark colors, with a consequent serious cheapening of his reputation as a whole.

One alternative, consistent with the view that the right serves importantly to protect the interests of the various owners of the artist's work, would be to give enforcement rights to those owners-for example, by letting any of those owners bring an action against another owner for harm to the integrity of the artist's work. This approach, however, has obvious weaknesses. Different owners of the artist's work might have very different ideas about the kinds of actions that are consistent with the right of integrity. One might hesitate giving to every owner of a work by Andy Warhol the right to bring an action seeking to enjoin any other owner of Warhol's work from restoring, reframing, or engaging in any other activity that might colorably be alleged to be an infringement of the artist's integrity. Nuisance litigation, and even opportunistic holdups, might become widespread. Similarly, if all owners were given enforcement rights, then the transaction costs of securing waiver (if the right is waivable-see below) would frequently be prohibitive. When only the artist has enforcement rights, in contrast, there is just a single, easily identified person from whom waiver must be purchased (thus meeting the second of the conditions discussed earlier that commonly characterize situations in which servitudes are enforceable). Consequently, there may be little practical alternative to making the artist the guardian, during his lifetime, for the interests of other owners and of the public in protecting the integrity of his work.

\section{After the Artist's Death}

If the right of integrity is to extend beyond the death of the artist, then there is of course no alternative but to find someone other than the artist who can exercise the power of enforcement. Again, one alternative is to give the power of enforcement to owners of the artist's work. But, presumably for the reasons just discussed, this has not been the approach taken. Rather, under European law, the right of integrity is generally passed on to the artist's heirs under rules analogous to those that govern his other prop-

${ }^{73}$ See Thomas J. Davis, Jr., Fine Art and Moral Rights: The Immoral Truth of Emotionalism, 17 Hofstra L. Rev. 317, 358-59 (1989). 
erty. Thus, he can designate in his will the person or persons who will have the authority to enforce his moral rights in his works and, absent such designation, the right will descend to his heirs according to law.

A problem with this approach, of course, is that the interests of an artist's heirs may diverge among themselves and may diverge as well from the interests of the current owners of the artist's works and of the public at large. ${ }^{74}$ An alternative is to give enforcement powers to a public authority after the artist's death. Italian law follows this course, giving the government rights of enforcement that coexist with those of the artist's heirs after his death. ${ }^{75}$ Moreover, in all countries that have legislation protecting the national cultural heritage, enforcement powers pass to a public authority once a work of art has fallen within the protection of that legislation. ${ }^{76}$

\section{G. Damages for Infringement of the Right of Integrity}

If, as suggested here, it is appropriate to view an artist who enforces his moral rights as representing not just his own interests but also the interests of other owners of his work and the interests of the public at large, then it follows that, in assessing damages for violations of the right of integrity, the amount of those damages should not be limited to just the pecuniary and nonpecuniary losses actually suffered by the artist but rather should reflect as well the losses suffered by others. While the consequence may be overcompensation for the artist himself, it is the measure necessary to provide appropriate incentives for potential violators of the integrity of the work, and any lesser measure would provide inappropriately weak incentives for the artist to bring suit.

Moreover, even as regards the artist himself, when assessing damages it is appropriate to consider the full extent of potential reputational injury that the artist might suffer, including injury to his ability to sell works he might create in the future. ${ }^{77}$

${ }^{74}$ See Museum Boutique Int'l v. Picasso, 880 F. Supp. 153 (S.D.N.Y. 1995) (dispute among Picasso's heirs about commercial licensing).

${ }^{75}$ Italian Copyright Law, supra note 19, art. 23. Notwithstanding the legislative intent to promote the public interest, the Califormia legislature omitted granting the state or a public interest group standing to enforce moral rights, apparently as a concession to opponents of those rights. See Gantz, supra note 33, at 887-90.

${ }^{76}$ The U.S. law on colorization also sets up a public commission that has the responsibility for deciding which films must include an announcement in the credits saying that they were colorized. 2 U.S.C. \& 179(b).

${ }^{77}$ When violation of the right of integrity threatens continuing harm, injunctive remedies must also be considered. The appropriate nature and scope of an injunction-destruction of the work, restoration, removal of the artist's name, labeling to disclose the alteration, etc.must then be decided. Although we believe that our discussion of the interests served by the right of integrity illuminates the issues involved in that choice, we shall not pursue them in detail here. 
As it is, VARA offers courts the potential for taking a broad view of damages along these lines, since it adopts the remedies available under copyright in general, which permit a court to assess statutory damages that exceed actual injuries provable by the plaintiff. ${ }^{78}$ Likewise consistent with this line of reasoning, U.S. state courts have been generous in giving artists damage awards in right-of-integrity cases that substantially exceed the artist's provable financial injury, though apparently often under the theory that the compensation is for emotional harm the artist suffers because of the mistreatment of his work. ${ }^{79}$

\section{H. Inalienability}

It appears that every jurisdiction that recognizes the right of integrity places restrictions on the artist's ability to alienate that right ${ }^{80}$ Those restrictions typically take one of two forms. First, there are jurisdictions, such as France, that make the right of integrity completely inalienable. ${ }^{81}$ Second, there are jurisdictions, such as the United States and England, that make the right nontransferable but waivable.

We shall examine these two regimes here in reverse order. Although our discussion is confined to the right of integrity, much of the analysis applies as well to the other moral rights, which in any given country are typically covered by the same restrictions on alienability that apply to the right of integrity.

\section{Rights That Are Nontransferable but Waivable}

Some countries grant artists a right of integrity that is nontransferable yet at the same time explicitly or implicitly permit artists to waive that right. Although this might at first seem contradictory, the resulting regime is quite coherent.

England offers a particularly clear example. By statute, English law specifically grants to artists moral rights, including the right of integrity, ${ }^{82}$ that

7817 U.S.C. $\S \S 501,504(c)$.

${ }^{79}$ See Peter Karlen, supra note 20.

${ }^{80}$ The Berne Convention does not specifically insist that moral rights in general be made inalienable, other than the droit de suite, although it has generally been interpreted to require inalienability. For a critique see, for example, J. Raynard, Droit d'auteur et conflit de lois 616-17 (1990).

${ }^{81}$ See Federic Poullard-Duhan, Moral Rights in France, through Recent Case Law, 145 R.I.D.A. 126 (1990); but see A. Strowel, supra note 15, at 497-98, describing the French rule as "la regle de l'inalienabilité ou de la renonciation (partielle)."

${ }^{82}$ Copyright, Designs and Patents Act (CDPA), 1988, §§ 77-89, 94-95, 103 (Eng.). What we are terming here the "right of integrity" is termed in the British statute the "right to object to derogatory treatment of work" and includes the right to object to, among other 
are "not assignable." ${ }^{83}$ The statute also provides, however, that an artist can freely "waive" his moral rights, in whole or in part, so long as the waiver is in writing. ${ }^{84}$ Moreover, if this waiver is "made in favour of the owner or prospective owner of the copyright in the work or works to which it relates," it is transferable to the latter's licensees or successors in title. ${ }^{85}$

The intent and effect of this English statute, it appears, is several. First, it permits an artist, if he wishes, to retain a right of integrity in his work whose burden runs with the work even after he has sold the work itself and the copyright to it. To the extent that these rights exceed those that could be reserved through retention of part or all of the artist's copyright, the right of integrity gives the artist powers to control uses of his work, through imposition of servitudes on it, that could not be constructed with the tools of contracting available in the common law.

Second, even to the extent that the right of integrity overlaps with rights that could be retained through limitations on the author's assignment of copyright, the separate statutory right of integrity creates a default rule under which, unless the right of integrity is specifically waived in whole or in part, it is presumed that the author retains the right to object to uses of his work that would violate that right even if he has assigned his copyright. If, as we have suggested, uses that would violate the right of integrity are generally inefficient uses of the work, then it can be assumed that artists in general would wish to prohibit such uses, and reading such a term into assignments of copyright will save contracting costs.

Third, by making the right "not assignable" but waivable, the statute is evidently seeking to bar the transfer of the right of integrity - that is, the right to object to mistreatment of the artist's work - to parties other than the current owner of the copyright to the work. The latter bar is not imposed, it seems, because there could never be good reason for a third party to have the power to enforce the right of integrity. As argued above, owners of other works by the artist, and also members of the public at large, can have an important interest in preventing alteration or other misuse of an artist's work. Rather, the bar is evidently imposed to prevent a fragmentation of

things, any alteration of a work that "amounts to distortion or mutilation of the work or is otherwise prejudicial to the honour or reputation of the author or director." Id. $\$ 80$.

${ }^{83}$ Id. $\& 94$.

84 Id. $\$ 83$.

${ }^{85}$ Id. $\$ 87(3)($ b). U.S. law appears more restrictive than English on assignability of the benefit of a waiver. Although VARA does not directly address the issue, the legislative history for that act contains the statement that "a waiver applies only to the specific person to whom waiver is made. That person may not subsequently transfer the waiver to a third party. Any third parties must obtain waivers directly from the author." 1990 U.S.C.C.A.N. 6915 , 6929. 
ownership rights in the work of art that, through high transaction costs and holdouts, could frustrate valuable uses of the work.

Moreover, the latter bar seems unlikely to prevent arrangements that offer important efficiencies. For example, it would not seem to prevent a painter from transferring to a trustee both his copyright and his moral rights in paintings he has sold, to be exercised by the trustee for the combined benefit of both the artist (or his estate) and other owners of the artist's works. Consequently, it is not surprising that all legal regimes that recognize the right of integrity apparently make that right (and other moral rights they recognize) nonassignable to third parties who lack a copyright in the work.

\section{Full Inalienability}

In some countries (France being the most extreme example), the right of integrity is made entirely inalienable. In effect, this does not mean that an artist cannot consent to acts that would violate his right of integrity, but rather than he cannot bind himself to such a waiver-that is, he cannot enter into an enforceable agreement not to change his mind in the future and seek a judicial remedy for the violation. ${ }^{86}$

a. Protecting the Artist. A popular explanation for making moral rights inalienable is that this protects the artist against exploitation by those to

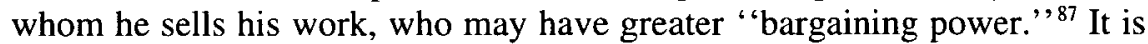
now a familiar point, however, that if individuals are well informed, one cannot make them better off by refusing to enforce contracts they might choose to enter into. ${ }^{88}$ Consequently, such an explanation for inalienability requires some further assumptions if it is to be persuasive. In particular, it is persuasive only if $(a)$ artists commonly undervalue the benefits they derive from the right of integrity and, $(b)$ for most artists, waiving the right of integrity would be inefficient (that is, the value of waiver to the owner of an artist's work would generally be less than the injury that the artist would suffer from waiver). Absent condition $a$, artists can safely be left to decide for themselves when to waive the right; absent condition $b$, the bet-

${ }^{86}$ C. Prop. Intellectuelle, supra note 19, Art. L. 121-1.

${ }^{87}$ See R. Veersteeg, Federal Moral Rights for Visual Artists: Contract Theory and Analysis, 67 Wash. L. Rev. 827, 847-50 (1992).

88 See Richard Epstein, Unconscionability: A Critical Reappraisal, 18 J. Law \& Econ. 293 (1975); Richard Craswell, Property Rules and Liability Rules in Unconscionability and Related Doctrines, 60 U. Chi. L. Rev. 1, 64 (1993); M. J. Trebilcock, The Doctrine of Inequality of Bargaining Power: Post-Benthamite Economics in the House of Lords, 26 U. Toronto L. J. 359 (1976). 
ter solution to the informational problem described in $a$ would be a regime with no right of integrity (for instance, forced waiver).

Whether condition $b$ holds depends on the scope given the right of integrity - a question we shall return to below. What about condition $a$ ? While, lacking extensive empirical data, one cannot say anything definitive, it would seem surprising if it were true. At least if, as in the British system, waiver must be explicit and in writing, then it is hard to believe that the average artist could not make an intelligent judgment about the costs and benefits of granting a waiver.

A slightly different quasi-paternalistic argument for inalienability might apply here, however, even if-indeed, especially if-artists in general are fully aware of the costs of waiver and prepared to refuse waiver when it is against their interests. If the overwhelming majority of artists would not agree to waive their moral rights, then giving them the opportunity to do so may be counterproductive. If a struggling artist whose wife and children are living in relative poverty must make an explicit decision, each time he sells a painting, to refuse greater financial income in order to retain his right of integrity, the result may be needless angst and guilt. Deciding whether or not to sell something can itself be costly - a point sometimes neglected in conventional economic analysis. Where it is perfectly clear that people would rarely sell a particular thing, then giving them the opportunity to do so may not make them happier. ${ }^{89}$

b. Protecting Third Parties. The fact that third parties-other owners of an artist's work, and the public at large-may benefit from the artist's right of integrity arguably makes a stronger case for unwaivability than does the paternalistic argument just discussed. If the artist could waive his right of integrity, he might do so in situations where waiver would be worthwhile for him but not for third parties-for example, as we suggested above, toward the end of his productive career. ${ }^{90}$ Of course, the extent of protection granted third parties by inalienability is limited, since the artist generally has the sole right to enforce the right during his lifetime, and third parties have no power to compel him to enforce the right. Nevertheless, the

89 See Henry Hansmann, The Economics and Ethics of Markets for Human Organs, $14 \mathrm{~J}$. Health Pol., Politics \& L. 57-85 (1989), reprinted in Organ Transplantation Policy: Issues and Prospects (J. Blumstein \& F. Sloan eds. 1989).

90 As cogently argued by Richard Epstein, the presence of externalities is also the most persuasive argument for inalienability in many other situations where such a rule is found. Richard A. Epstein, Why Restrain Alienation? 85 Colum. L. Rev. 970 (1985).

Recent U.S. legislation on film colorization, which requires maintenance of uncolorized originals in the case of films deemed to be important, presumably must be justified along these lines: it imposes costs on current owners of films for the sake of conferring (presumably larger) benefits on the public at large. 2 U.S.C. $\$ 179$. 
artist's inability to grant a binding waiver is likely to inhibit many owners from acts that would clearly violate the integrity right.

Moreover, artists themselves may have an interest in being bound not to waive their right of integrity, since the consequence could be an increase in the prices they receive for their works in general. Purchasers of an artist's work might value some reassurance that the artist has committed himself never to compromise his reputation; consequently, they might be willing to pay more for the work of an artist who has done so. Such a commitment is difficult to make by ordinary contractual means, however: its benefit-that is, the ability to enforce the commitment-will not run to subsequent purchasers of the artist's work, and even the initial purchaser who personally obtains such a commitment from the artist will have no ability to nullify any subsequent waiver that the artist enters into contrary to his promise but rather will have recourse only to damages from the artist as a remedy for the latter's breach. By making the right of integrity unwaivable, in contrast, the law makes the commitment not to waive much more credible.

\section{Degrees of Waivability}

Potential doctrinal approaches to waivability of the right of integrity span a broad spectrum. We have just considered one extreme, in which the right is entirely inalienable. At the other extreme, the law can recognize a right of integrity but assume that the right is waived unless explicitly reserved by the artist. The latter regime appears not to exist. It might not, however, be pointless, since it would permit an artist to do what she otherwise might not be able to do simply with copyright, namely, impose a servitude on her works for purposes of preventing certain types of use or abuse.

English law presents an intermediate point on the spectrum: moral rights are presumed to be retained by the artist unless specifically waived, but can be waived to any extent the artist desires. It is sometimes argued that this regime does not provide an artist with any greater protection that the regime described in the preceding paragraph, under which moral rights are simply presumed to be waived. ${ }^{91}$ After all, it is said, if an artist is free to waive his moral rights, then purchasers of his work will always insist that a contract of sale include such a waiver, and such a term will simply become a standard form in contracting. In fact, however, artists do not waive their moral rights routinely in jurisdictions that permit waiver. ${ }^{92}$ This is not surprising.

${ }^{91}$ See, for example, G. Dworkin \& R. Taylor, Blackstone's Guide to the Copyright, Designs \& Patents Act 1988, at 101 (1990).

${ }_{92}$ For example, in California, which has a state moral rights statute granting the right of integrity, " $[w]$ ith most commissioned works, the agreement between the parties usually does not have a waiver clause. But contracts for large public works, commissioned by a developer or public agency, often contain a waiver clause." Karlen, supra note 20, at 936 . Of course, 
The requirement of an explicit waiver in writing alerts the artist to the possibility of retaining the rights if he wishes or of insisting on greater compensation if he agrees to the waiver. Further, it creates a degree of moral or psychological pressure for the parties to refrain from full waiver in some circumstances. Finally, it gives the courts the opportunity to scrutinize waivers and to interpret them narrowly and against the party that drafted them-which is not likely to be the artist but rather the purchaser or a broker such as a gallery.

There is also the question of the scope of individual waivers. English law, as we have noted, permits a blanket waiver of all of an artist's right of integrity and also permits the benefit of any waiver, whether broad or narrow, to run to subsequent purchasers of the work. Under Italian law, in contrast, it appears that the artist cannot execute a blanket waiver and that the benefit of a waiver will not run with the work; rather, an artist can waive his right to object only to specific alterations undertaken by specific individuals. The latter approach, of course, assures that the artist has specifically approved any alterations and, hence, provides more careful protection of the interests of all parties protected by moral rights doctrine, while increasing the costs of obtaining waivers.

\section{How Broadly to Interpret the Right of Integrity?}

As we have already suggested, it makes sense to make the right of integrity unwaivable only if waiver of the right would generally be inefficient. But the general inefficiency of waiver depends, in turn, on how broad the right is. If, on the one hand, we interpret the right of integrity to extend to any alteration whatsoever of a work of art, then making the right unwaivable may well prevent many potentially efficient transactions. On the other hand, if the right of integrity is interpreted as extending only to "abusive", or "degrading" modifications or uses, or to "mutilation" of the work, then, almost by definition, waiver would be inefficient.

This suggests that it makes sense to turn the issue around: in regimes where the right of integrity is made unwaivable, it is appropriate to interpret the right narrowly to cover only uses or abuses of an artist's work that would clearly be inefficient. In effect, there is a choice here-as in the case of display rights discussed above-between a tort-type rule and a propertytype rule. An unwaivable right that is narrowly formulated looks more like a tort-type rule, providing a cause of action for any unreasonable (inefficient) alteration of the work. Under a property-type rule, in contrast, a

large commissioned public works are precisely those for which waiver is most likely to be efficient. 
broad range of alterations can be made enjoinable, and it can be left to the artist, via waiver, to decide which particular alterations will be permitted.

Note that, even with a narrow tort-type right of integrity that is unwaivable, there is still potentially room for substantial contracting between an artist and the owners of his work concerning treatment of the artist's work. As we have observed above, an artist's copyright - in particular, the right to create adaptations or derivative works-gives artists the right to object to uses of his work that might not be sufficiently derogatory to constitute violations of the right of integrity. By deciding what, if any, types of adaptations or derivative works he will license, an individual artist can choose for himself how much protection he wishes to have beyond that afforded simply by the right of integrity.

\section{The Right of Attribution}

The right of attribution, or paternity, has two aspects. The first, which we can call the affirmative aspect, is the artist's right to insist that her name continue to be associated with a work of art she has created even after she has entirely parted with her copyright in the work and, in the case of unique works of visual art, with the work of art itself. The second, which we can call the negative aspect, is the right to insist that her name not be used on works she has not in fact produced, and perhaps not on those that she has produced as well. ${ }^{93}$ We shall deal with the negative aspect first, then the affirmative.

\section{A. The Negative Right of Attribution}

Most jurisdictions, it appears, permit artists to insist that works of artwhether they are literary works or works of visual art-not be attributed to them if they have not in fact created them. Some jurisdictions-including the United States (for visual arts) after the adoption of VARA-include this right as part of moral rights doctrine under the right of attribution. ${ }^{94}$ Other jurisdictions do not, but then effectively recognize the right under another doctrinal label, such as the right of privacy. ${ }^{95}$ This negative right is relatively unproblematic. It has obvious utility in protecting artists from theft

9317 U.S.C. $\$ 106$ A; C.D.P.A. $\$ 84$ (false attribution); Id. $\S 77$ (paternity); C. Prop. Intellectuelle, supra note 19, Art. L. 123-3, at 3; German Copyright Act, supra 19, art. 66(2), at 14; Italian Copyright Act, supra note 19, art. 21(1), at 4.

9417 U.S.C. $\S 106 \mathrm{~A}$.

95 See the "Emil Nolde" case decided by the German Federal Court of Justice, June 8, 1989, 22 I.I.C. 273 (1991). 
of the reputation they have cultivated and in protecting the public at large from being misled. ${ }^{96}$

A more interesting question is whether the negative right of attribution should cover artists who wish to deny association with works that they have in fact produced. Consider, for example, the situation in which the publisher of a book originally published pseudonymously wishes to (re)publish-or simply advertise - the work under the author's true name after the author has subsequently become famous for other work. ${ }^{97}$

One might argue that the interest of the public at large in knowing the author's true identity should be given weight here, and thus the publisher should prevail. That is, one might consider pseudonymous works to be a sort of fraud on the public and, while not going so far as to outlaw the use of pseudonyms entirely, leave publishers free to abandon the fraud whenever they wish by revealing the author's true identity.

However, it appears at most a modest fraud on the public to publish a work pseudonymously. Or at least this is true if the pseudonymous author is a pure invention, rather than a real person who is different from the actual author-the latter being the type of situation involved in ghostwriting, which we discuss below. Where the pseudonymous author is a pure invention, the use of a pseudonym does not so much deceive the public as deny them information - the identity of the real author - that they might like to have. And thus one can perhaps feel comfortable with letting the author and the publisher decide whether they wish to sell that information. The author, moreover, may have strong interests in not disclosing. Most obviously, he may wish to protect the public image as an author that he has developed under his true name and not have it confused or adulterated by having the same name associated with works of a different character. That is, the artist may have good reasons to exist in the public's mind as two different artists - publishing works, as it were, under two different trademarks. Moreover, even where it is efficient to have the artist's true name publicized with his formerly pseudonymous work, if a publisher did not initially pay the artist for that right, it is appropriate to make him offer the author additional compensation in order to have it. Otherwise, the publisher is in a position to free ride on the efforts of the author to develop a reputation under his

${ }^{96}$ See the discussion of the analogous commercial "right of privacy"' in Richard Posner, The Right of Privacy, 12 Ga. L. Rev. 393 (1978).

${ }_{97}$ See, for example, Ellis v. Hurst, 128 N.Y.S. 144 (1910), aff'd 130 N.Y.S. 1110 (1911) (author of book published under a nom de plume before author became famous under his true name cannot enjoin publisher of book from republishing it with author's true name); compare Follett v. New American Library, 497 F. Supp. 304 (S.D.N.Y. 1980) (coauthor of book can prevent publisher from publishing the book, after the author has become famous for other work, with an attribution misleadingly proclaiming coauthor as principal author). 
true name and on the efforts of other publishers who have purchased and promoted works under the author's true name. A publisher with the rights to a pseudonymous work has purchased only a given authorial image or reputation-not necessarily the true persona of the author.

The same analysis applies even more strongly to works published anonymously. By permitting the authors of such works to decide whether to disclose their true identity, the law can effectively and appropriately internalize to authors the costs and benefits of that choice. And here there is no offsetting concern that the public will be deceived into believing that there is some person other than the true author who has written the work in question.

It is for such reasons, presumably, that the law in many civil-law jurisdictions expressly recognizes the right of an author to publish pseudonymously or anonymously. ${ }^{98}$

The analysis changes when an artist, after selling the copyright to his work or (in the case of the visual arts) the work itself, seeks to deny the right to use his name in connection with the work. A famous case involves the Italian painter De Chirico, who denied publicly that he had painted a given painting that bore his signature and that, subsequently, was proven to have in fact been his work. Far from succeeding in disassociating his name from the work, De Chirico was forced to pay damages to its current owner for injuring its marketability by his disclaimer. ${ }^{99}$ This of course makes good sense: the artist's reputation is an important part of what the owner of the work purchases when he acquires one of the artist's paintings.

\section{B. The Affirmative Right of Attribution}

Like the right of integrity, the affirmative right of attribution-the right of the artist to insist that his name continue to be associated with a work that he has created-derives much of its importance from the fact that each work by a given artist gains value from its association with the artist's other work. To remove the artist's name from one of her works is to remove that work from the artist's oeuvre as a whole and, thus, to diminish the value of the other works that make up that oeuvre. Thus, as a general rule, not only the artist herself, but also the other owners of the artist's works and perhaps the public at large, have an interest in assuring that the artist's name continue to be associated with each of her works. The right of attribution gives an artist the capacity to insist that this be done by effec-

98 C. Prop. Intellectuelle, supra note 19, Art. L. 123-3; German Copyright Act, supra 19, art. 13; Italian Copyright Act, supra note 19, art. 21.

99 Tribunale di Roma, March 20, 1965; Foro Italiano 1966 II, 513. 
tively imposing and enforcing a servitude on her work to that effect. While, in the United States, copyright law would seem to be sufficient for this purpose for literary works, arguably it is not for works of visual art, so that the right of attribution explicitly granted by VARA to visual artists expands the latter artists' capacity to tie their name to their work..$^{100}$

The most intense controversies concerning the right of attribution involve questions of inalienability. English and U.S. law make the (affirmative) right of attribution waivable, while civil-law jurisdictions often do not. We shall focus here brieffy on several areas in which this difference of approach arises conspicuously.

\section{Pseudonymous Writings}

Suppose that an author, in an earlier phase of his career, created a number of works under a pseudonym, and now wants to have his true name put on those works. Does he have the right to insist on that now, even if his original contract denied him that right and the publisher who owns the copyright does not agree? In the civil-law countries the answer is generally yes: the author has the right to have his true name associated with the work, regardless of any contractual commitments to the contrary. ${ }^{101}$

There are, however, persuasive reasons for denying authors such an inalienable right. Suppose, for example, that the author involved had written two types of books: one a popular series of romances, under a pseudonym, and the other a set of more serious novels under his own name. And suppose that the pseudonymous romances had been carefully and successfully marketed to be of a particular type - all Regency romances, say, with particular types of plot lines and characters-and the pseudonymous author had been made an expression of this type, perhaps by using a female pseudonym of distinctly British character. The author might at some point decide that he would like to have his true identity attached to the romances, either to boost the sales of his more serious but less marketable novels, or simply to gain notoriety. The publisher might protest, however, on the

\footnotetext{
100 For example, a sculptor who, for esthetic reasons, signed one of his works on the bottom, where the signature would not be visible when the work was displayed, might want to insist that the work always be displayed with a label giving the sculptor's name. But, since display rights are explicitly excluded from copyright in the United States, he arguably could not impose an enforceable condition to this effect on all subsequent owners of the work. Under VARA, he would have a stronger-though not unambiguous-claim to such a capacity. See Peter Karlen, What's Wrong with VARA: A Critique of Federal Moral Rights, 15 Hastings Comm. \& Ent. L. J. 905, 913 (1993).

101 Italian law, for example, explicitly states that an author of an anonymous or pseudonymous work retains the right to insist that, in the future, her name be associated with the work. Italian Copyright Act, supra note 19, art. 21.
} 
grounds that the publisher's financial returns would suffer badly from the disclosure. Here one could well argue that the author should not be given the right to insist on disclosure, and surely not without compensating the publisher. In effect, the author is seeking to alter the trademark under which the publisher has carefully marketed the romances.

\section{Work for Hire}

The common-law countries have, as part of their copyright law, a workfor-hire doctrine under which an individual who is employed to create a work "for hire" is not granted copyright in the work; rather, copyright in the work is held, from the beginning, by the individual's employer. In those common-law countries that recognize artists' moral rights, an individual who works for hire is also denied moral rights, including the right of attribution. $^{102}$

This approach is consistent with the functions that we have been attributing here to moral rights doctrine. Work for hire, in general, is work that is subject to substantial control by the person who commissions the work. As such, it has less connection with the personality of its creator, and the collected body of work that a given individual does for hire has less in common as an oeuvre, than in the case of work done more independently. Consequently, the interests of the artist that are protected by moral rights doctrine are less in evidence in work for hire than they are in other forms of creative work. Or, put differently, work for hire is not "art" in the sense we have spoken of above. And, even if it does qualify for status as "art" in that sense (think of magazine covers whose artist is unmistakable, or films that bear the clear imprint of their director), one can argue that the fact that the work is done for hire constitutes a waiver of moral rights, in recognition by the artist and the commissioning party that the latter's need for flexibility in the use of the work exceeds the artist's subjective and reputational interests. ${ }^{103}$

A seemingly fundamental difference between civil-law and common-law jurisdictions is that only the latter recognize the work-for-hire doctrine. ${ }^{104}$ Yet the civil-law jurisdictions arguably reach similar results by other means. Italian law, for example, grants moral rights to the "author" of a

${ }^{102}$ This is the case in the United States, for example, under VARA. 17 U.S.C. $\$ 101$ ("a work of visual art does not include ... any work made for hire').

${ }^{103}$ See Carter v. Helmsley-Spear, Inc., 71 F.3d 77 (2d Cir. 1995), discussed in note 39 supra.

104 See Adolf Dietz, The Concept of Author under the Berne Convention, 155 R.I.D.A. 21, 36-40 (1993). 
work, without making exceptions for authors working for hire. ${ }^{105} \mathrm{But}$, in those circumstances in which a common-law court would hold that an individual was merely working for hire, and hence not entitled to assert the right of paternity or other moral rights, Italian law would quite likely find that the individual was not the "author" of the work on which he labored, and for that reason not entitled to claim moral rights. ${ }^{106}$

\section{Ghost Writers}

The French courts have held that the right of paternity extends to ghostwriters and, since moral rights are inalienable in France, have further held that a ghostwriter who has contractually waived the right to have her name associated with a publication she has written can later renege on that waiver and insist that her authorship be recognized. ${ }^{107}$ Arguably the law is similar in other civil-law jurisdictions as well. ${ }^{108}$ Such an unwaivable right to claim authorship is clearly a strong obstacle to ghostwriting, the whole point of which is to obscure the true authorship of the work. Why create such an obstacle?

One reason might be to protect the public against misrepresentation. If one views ghostwriting as a form of literary fraud, then there is every reason to refuse to enforce the contracts through which it is undertakenwhich is what an unwaivable right of paternity does. This may be a sufficient justification for a position such as that taken in France. But there are several reasons to take the opposite view.

First, giving a ghostwriter an inalienable right of paternity is arguably a poor way to protect the public's interest in the integrity of authorship, since

\footnotetext{
${ }^{105}$ Italian Copyright Act, supra note 19, art. 20 (granting right of paternity and integrity to "author" of work).

106 On the other hand, there are areas in which there are clear differences between the results reached in the common-law and civil-law systems. One conspicuous example is film. The common-law countries assume that the director of a film works for hire, and that the producer holds the copyright to the film, while the civil-law countries generally assume that the director of a film is an "author" and as such has moral rights in the film (although special rules governing film may limit the director's power to assert his moral rights). See Huston v. Societé de l'Exploitation de la Cinquieme Chaine, 1991 Cass. civ. 1re, 149 R.I.D.A. 197 (Cour de cassation).

107 See Bragance v. Michel de Grece et Editions Orban, Court of Appeal of Paris, February 1, 1989, 142 R.I.D.A. 301 (1989).

108 For example, from the Italian statute, supra note 101, explicitly giving the author of an anonymous or pseudonymous work the right to insist, in the future, that her name be associated with the work, one could argue that ghostwriters also should have the right to claim authorship. As it is, in Italy a contract with a ghostwriter commonly characterizes the ghostwriter not as the "author" of the work but simply as somebody who assists the nominal author and by this means seeks to avoid extending moral rights, including in particular the right of attribution, to the ghostwriter.
} 
it does not prevent ghostwriting in situations in which the ghostwriter can be depended on not to sue for his right of integrity - as a professional ghostwriter presumably would not, for fear of ruining his professional reputation. Second, the degree of misleading is likely to be small where ghostwriters are involved. Ghostwriters are apparently most often used in cases where the nominal author can be expected to produce only one book-commonly his (auto)biography. In that case, there is little misleading of the public involved, in the sense that the public will not be led to purchase subsequent books by the same nominal author on the assumption that they will be as good as the ghostwritten book.

Here, again, it is helpful to address the question along the lines of our preceding discussion of "What is art?' for purposes of moral rights doctrine. A ghostwriter's skill is, in important degree, to be able to suppress her own personality when writing and to capture, instead, the style and character of the nominal author for whom she is working. Consequently, a ghostwriter-at least when she is serving as ghostwriter, rather than as author in her own right--is typically not the kind of person whose works as a group have special value connected with the personality of their creator; that is, the ghostwriter is not creating "art" in the sense we described above. It follows, in turn, that there is less reason to extend to ghostwriters than to other writers or artists the protection of moral rights doctrine, including the right of paternity.

\section{The Right of Disclosure}

Under the right of disclosure, an artist is given complete discretion to determine if and when his work is ready to be displayed to the public.

One application of the right has been to grant to artists the power to determine that work they are doing under commission is not yet ready for delivery. ${ }^{109}$ In such circumstances, the right of disclosure does not free the artist from the obligation to pay damages for failure to perform his contract. Rather, it effectively amounts to a refusal to grant specific performance on a contract for a work of art.

Another context in which the right has arisen involves work discarded by an artist. A French case, for example, involves an artist who became dissatisfied with several paintings he had made and threw them out. Somebody else recovered them, and they were ultimately put up for sale, identified as work of the artist. The artist sued to enjoin the sale, and won, with the argu-

109 In the most famous application, the French courts sustained the willful refusal by James McNeill Whistler to perform on a commission for a portrait. Judgment of April 14, 1900, Cour de cassation, 1900 D.P.I. 497 (Fr.). 
ment that, although property law would normally give title in the discarded items to the person who found and recovered them, the artist had the sole right to decide whether that artistic work could be disclosed to the public. ${ }^{10}$

\section{A. The Right as a Default Rule}

Viewed simply as a default rule to be applied in the absence of specific commitments by the artist to the contrary, the right of disclosure has obvious merit. An artist-and perhaps other owners of the artist's work as well-might suffer substantial subjective or pecuniary injury from exposure of work the artist considers unworthy of his talents or inconsistent with the image he wishes to project, and the potential for such injury might be difficult to predict in advance, when the commission for a work is entered into. (Alternatively - or what may be the same thing - the cost to the artist of completing the work satisfactorily might unexpectably prove far higher than originally estimated.) While an artist could always protect himself from such injury, even absent the right of disclosure, by buying back the rights to the work, the necessary negotiations could be costly or unsuccessful, especially where the potential injury to the artist substantially exceeds the value of the work to the other party, hence inviting extortionate holdup of the artist. Moreover, the damages that will be suffered by the purchaser (or, in the case of recovered rejects, the current owner) as a consequence of nondisclosure should often be relatively easy for a court to assess, since testimony can be gathered as to, for example, the market value of a work by the artist originally contracted for, or the cost of commissioning a substitute. ${ }^{111}$

\section{B. Inalienability}

In some civil-law jurisdictions, including France, the right of disclosure is inalienable. This means, in effect, that an artist who accepts a commission to create a work of art cannot commit herself, by contract, to specific performance of that commission. This goes beyond the conventional notion that specific performance is an inappropriate remedy for a contract for labor services. Even where an artist has produced and delivered a work to the

110 Carco v. Camoin, D.P. II 88 (Cour d'appell, Paris) (1931). See Stella v. Mazoh, No. 076 85-82 (N.Y. Sup. Ct., April 1, 1982); Franklin Feldman \& S. E. Weil, 1 Art Law: Rights and Liabilities of Creators and Collectors 508-9 (1986).

III These issues are in some degree analogous to those involved in an author's right to prevent publication by others (such as a biographer) of personal letters written by the author. See Landes, supra note 14. Indeed, while the latter issue is governed by the law of copyright in the United States, it is covered by moral rights doctrine-the right of disclosure-in Europe. 
person who commissioned it, and the latter person wishes to accept the work as adequate performance of the contract, the artist retains the right to declare the work unsuitable for public display and to enjoin such display, subjecting herself at most to payment of damages to the purchaser, and perhaps only to return of her commission. ${ }^{112}$

Why prohibit artists from entering into contracts that waive the right of disclosure-that is, that give the purchaser the option to accept, as satisfactory performance, work with which the artist is unsatisfied? Perhaps the most persuasive justification (if there is justification at all) is the same as that which might be offered in other situations in which the law will not enforce commitments for specific performance-namely, that, in the great majority of cases, such a contract would be inefficient (in this case, for the reasons given in the preceding section). Thus, when such a contract is encountered, one might generally assume that it was entered into without full appreciation of its potential consequences.

There are, to be sure, situations in which it would clearly make sense for an artist to waive the right of disclosure at the time of contracting for creation of a work. In particular, a waiver would seem appropriate where the work is designed to fulfill a specific need of the purchaser for which damages would be difficult to assess objectively, while at the same time the artist's reputation is unlikely to be much affected by the quality of the work. Works covered by the work-for-hire doctrine in the common-law countries are likely to fall in this category, which is consistent with the exemption of work for hire from moral rights doctrine. (Uncompleted work done for hire, like completed work, belongs to the principal, who can do what he wants with it.) ${ }^{113}$ And in the civil-law countries, as we observed above, where an individual produces work that would be considered work for hire in a common-law jurisdiction, that individual would often not be considered the "'author" 'of the work, and hence would not be granted moral rights, including the right of disclosure. For example, suppose that a publisher contracts with a writer to write articles for an encyclopedia, and that the publisher puts a clause in the contract stating that the publisher shall have the sole right to determine when the work is ready to be published. If the publisher decides that the work is ready to publish, but the writer declares that he considers the work not yet completed or satisfactory, the writer may be un-

\footnotetext{
112 For example, Italian law expressly gives the author the right to block publication just by expressing his desire that it not be published, even when the material is in the hands of (consigned to) the publisher. Italian Copyright Act, supra note 19, art. 121. Moreover, this right is not waivable.

113 To be sure, none of the common-law countries presently grant an unwaivable right of disclosure to work of any sort, so the exemption from moral rights for work for hire is superfluous for this purpose.
} 
able to block publication on the grounds that the publisher, and not the writer, is the "author" of the work.

One can imagine that, for movies, an inalienable right of disclosure could be a major obstacle to production. Production companies might be very hesitant to provide financing for a film if the director or screenwriter could, even after the film had been largely completed, decide that they did not wish it to be distributed. Presumably for this reason, the civil-law countries have adopted special statutory provisions excepting film from rigorous application of the right of disclosure. Italian law, for example, provides that, although the screenwriter, director, scenographer, and composer are "authors" of a film for purposes of moral rights doctrine in general, those individuals do not have an unfettered right to block distribution of the film; rather, if they object to distribution, the producer can put the issue to arbitration by a panel of experts. ${ }^{114}$

\section{The Right to Withdraw}

The last of the basic moral rights is the right to withdraw a work from public exposure, even after the artist has sold the work. In strong contrast to the other moral rights, this right is available only to authors of published works and not to visual artists. ${ }^{115}$ An author who asserts this right must indemnify the copyright holder for damages suffered as a consequence of the exercise of the right. Moreover, some jurisdictions require that, before permitting an author to exercise this right, a court must determine that the author will otherwise suffer grave moral damage. ${ }^{116}$

This right is rarely exercised, both because the author must make an affirmative showing of severe harm and because the only art form for which it is available, namely, literary works, are as a practical matter very difficult to withdraw. Indeed, one might suppose that the right is basically empty, since it apparently does not give the author the right to repossess copies of a work that have already been sold to the public, but rather just permits the author to recover the copyright from the publisher and to prevent further distribution.

Nevertheless, the right could have value to an author. An illustrative situation involves the son of Charlie Chaplin, who at the age of 19 sold to a publisher the copyright to his life story, which was written by ghostwriters. The story was harshly critical of both of the author's parents and cast the

\footnotetext{
114 Italian Copyright Act, supra note 19, art. 47.

115 See Cour de Paris, judgment of April 19 (1961), J.C.P. III N. 12183 (1961) (French case denying right of withdrawal to Vlaminck).

116 Italian Copyright Act, supra note 19, arts. 142, 143.
} 
author in an unattractive light as well. Young Chaplin subsequently regretted the act and sued to block publication. He brought his case in England, which did not recognize the rights of disclosure or withdrawal, and was unsuccessful. ${ }^{17}$ Suppose, however, that he had brought suit in a jurisdiction that recognized the right of withdrawal and that copies of the book had already been sold and could not be recovered. Would withdrawal have been valueless? Not necessarily. Chaplin's son might well have felt that the act of withdrawal would itself be an important signal of his changed feelings and would also prevent the continuing sense of injury that he and his family might feel if copies of the book continued to be sold.

To be sure, even absent the right of withdrawal, an author such as Chaplin's son is always free to repurchase the copyright to his work from a publisher. Why go further and give authors the right to take back the copyright through compulsion rather than negotiation? A persuasive answer is analogous to that offered above in discussing the (closely related) right of disclosure. In those circumstances in which an author would wish to withdraw his work, a publisher might have both the incentive and the opportunity to seek to extract from the author a price far in excess of the loss to the publisher from giving up the right to publish the book. Giving the author a right of withdrawal here, conditioned only on compensating the publisher for the actual damages he will suffer, avoids both an unattractive redistribution from author to publisher and also the possibility that the publisher's effort to hold up the author will lead to costly bargaining or even an inefficient failure of the repurchase itself.

Such a view of the function served by the right of withdrawal explains why some jurisdictions permit exercise of the right only with a showing of "grave moral damage" to the author. This requirement helps assure that the right will be invoked only where the potential efficiency gains from withdrawal are high, the potential extortion is large, and the possibility that a voluntary transaction will fail is serious. It also assures that the author is not seeking to use the right of withdrawal simply to repossess cheaply a copyright that he thinks he can subsequently sell again for a higher price. ${ }^{118}$

Does it make sense to grant the right of withdrawal only for literary works and not for other types of artistic production, such as paintings? ${ }^{119}$

117 Chaplin v. Leslie Frewin (Publishers) Ltd., ch. 71 (1965), 3 All E.R. 764.

118 French law, C. Prop. Intellectuelle, supra note 19, Art. L. 123-3, does not require a showing of special damage to the author as a prerequisite to the exercise of the right of withdrawal-a fact that has been, understandably, the subject of much controversy. Also see $\mathbf{n}$. 121 infra and accompanying text.

119 In the European literature, there has been some discussion of extending to visual artists either the right of withdrawal or, less drastically, rights that go in that direction, such as a right of first refusal that would permit an artist to repurchase his work, when the current 
Perhaps so. The asymmetry in value between artist and current owner that we have just described, in which the harm to the artist from continued circulation of his work substantially exceeds the benefit to the owners of the work, seems less likely to arise in the case of visual art than in the case of written works, for reasons that the Chaplin example suggests: it is easier to make seriously embarrassing statements with words than with paint (though it is of course possible in the latter medium as well). Consequently, a right of withdrawal for paintings or sculpture would yield few serious benefits, while offering substantial scope for artists to behave opportunistically or eccentrically. Moreover, to be meaningful, a right of withdrawal for a painter or sculptor would have to permit the artist to reclaim not just the copyright to reproduction of the work, but more importantly the physical work itself. Given the endowment effect-the tendency of individuals to value a physical object much more highly if it is in their possession than if it is not ${ }^{120}$-appropriate damages for repossession of such works would be difficult to measure and might be substantially underestimated by the objective measures available to a court, such as market values.

The right of withdrawal is generally inalienable. In those jurisdictions that restrict exercise of the right to situations involving "grave moral damage," inalienability does not seem troublesome. That restriction, together with the requirement that the author compensate the copyright holder, provides substantial assurance that withdrawal will occur only where that is the efficient result. In those jurisdictions, such as France, where the statutes do not include the "grave moral damage" limitation, one might think that inalienability would mean that authors cannot renounce their ability to act opportunistically in reclaiming their copyright whenever this seems profitable to them and, thus, would impose inefficiency on publishing contracts. But, even in the latter jurisdictions, the courts seem unwilling to enforce the right of withdrawal when they believe that the author is acting opportunistically. ${ }^{121}$

\section{Why Did the U.S. Adopt Moral Rights Only Recently?}

One might well wonder why moral rights legislation has been adopted in the United States only recently, many decades after similar doctrine had become commonplace in Europe. One answer may be that, here as in other

owner has already negotiated a sale of the work, at the same price for which it was to be sold. Note that this latter approach avoids the endowment effect problem discussed immediately below. Compare Dietz, supra note 11.

120 See Daniel Kahneman, Jack Knetsch, \& Richard Thaler, An Experimental Test of the Endowment Effect and the Coase Theorem, 98 J. Pol. Econ. 1325 (1990).

${ }^{121}$ Cass. civ. Ire, May 14, 1991, 151 R.I.D.A. 272 (1992). 
areas of intellectual property, nations that are principally importers rather than exporters have little incentive to protect the interests of producers. American artists, in contrast to their continental counterparts, achieved substantial prominence in painting and sculpture-the principal fields advantaged by U.S. moral rights legislation-only in recent decades. Although Americans were serious collectors of fine art long before then, that art was largely of foreign origin, and it may not have been in the nation's interest to protect the foreign creators of that art, or the interests of foreign collectors or admirers of that art, with American legislation. The increasing scope of markets for fine art-a phenomenon not confined to the United Statesmay also have given increasing importance to moral rights and related doctrines that protect reputational interests in works of art. As those markets expand, so does the reward for being successful in them and, hence, the potential return from a strong reputation.

It may also be, however, that less direct economic interests were at stake. As American exports of material covered by conventional copyright-including books, movies, and recordings-have increased in importance, the nation's stake in having rights to those works enforced in foreign nations has also increased. Signing the Berne Convention was presumably motivated in important part by a desire to fortify enforcement of those rights, and enacting moral rights legislation for visual artists might in turn have seemed a relatively costless step toward showing good faith compliance with the Berne Convention.

\section{CONCLUSION}

For observers sophisticated in economic analysis, the recent spread of moral rights doctrine from the civil-law systems to the common-law systems might at first seem regressive-a well-intentioned but ultimately misguided and counterproductive effort to protect artists and artworks by imposing paternalistic restrictions on contracts and property rights. Perhaps there is some truth to such a characterization. But there is an important sense in which moral rights doctrine expands freedom of contract in intellectual property, since it permits the creation of divided property rightsservitudes on chattels - that could not be formed under the conventional law of property and contract. Those servitudes can potentially serve a useful role in the field of fine arts, particularly in controlling reputational externalities.

In common-law countries such as the United States, the law of copyright alone, even without the addition of special moral rights doctrine, gives authors and artists sufficient flexibility to protect themselves from many of the harms to which moral rights are addressed. This is particularly true where 
manipulation of the work involves the creation of reproductions. The potential contribution of moral rights doctrine is therefore more conspicuous where copyright does not reach, such as the display of original works of painting and sculpture. At the same time, the overlap between moral rights and copyright emphasizes the extent to which copyright itself serves to give authors and artists continuing control over the way in which their work is exploited and, hence, over their reputation. 


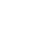

